San Jose State University

SJSU ScholarWorks

Master's Theses

Master's Theses and Graduate Research

Spring 2019

\title{
The Life History of the Southern Lanternshark, Etmopterus granulosus, from the Southwestern Indian Ocean
}

Melissa Nehmens

San Jose State University

Follow this and additional works at: https://scholarworks.sjsu.edu/etd_theses

\section{Recommended Citation}

Nehmens, Melissa, "The Life History of the Southern Lanternshark, Etmopterus granulosus, from the Southwestern Indian Ocean" (2019). Master's Theses. 5011.

DOI: https://doi.org/10.31979/etd.bdm2-twwy

https://scholarworks.sjsu.edu/etd_theses/5011

This Thesis is brought to you for free and open access by the Master's Theses and Graduate Research at SJSU ScholarWorks. It has been accepted for inclusion in Master's Theses by an authorized administrator of SJSU ScholarWorks. For more information, please contact scholarworks@sjsu.edu. 
THE LIFE HISTORY OF THE SOUTHERN LANTERNSHARK, ETMOPTERUS GRANULOSUS, FROM THE SOUTHWESTERN INDIAN OCEAN

\author{
A Thesis \\ Presented to \\ The Faculty of Moss Landing Marine Laboratories \\ San José State University \\ In Partial Fulfillment \\ of the Requirements for the Degree \\ Master of Science
}

by

Melissa C. Nehmens

May 2019 
(C) 2019

Melissa C. Nehmens

ALL RIGHTS RESERVED 
The Designated Thesis Committee Approves the Thesis Titled

THE LIFE HISTORY OF THE SOUTHERN LANTERNSHARK, ETMOPTERUS

GRANULOSUS, FROM THE SOUTHWESTERN INDIAN OCEAN

by

Melissa C. Nehmens

APPROVED FOR THE DEPARTMENT OF MARINE SCIENCE

SAN JOSÉ STATE UNIVERSITY

May 2019

Dr. David A. Ebert Moss Landing Marine Laboratories

Dr. Scott L. Hamilton Moss Landing Marine Laboratories

Dr. Kenneth H. Coale Moss Landing Marine Laboratories 


\title{
ABSTRACT \\ THE LIFE HISTORY OF THE SOUTHERN LANTERNSHARK, ETMOPTERUS GRANULOSUS, FROM THE SOUTHWESTERN INDIAN OCEAN
}

\author{
by Melissa C. Nehmens
}

The Southern Lanternshark, Etmopterus granulosus, is a deep-sea shark that associates with seamounts and ridges between 220-1500 m throughout the southern oceans. Though not a targeted species, it is frequently incidentally caught in several fisheries, and comprises the highest amount of bycatch by number in the Orange Roughy (Hoplostethus atlanticus) fishery in the Southwestern Indian Ocean. Despite how frequently this species is encountered, surprisingly little is known about it beyond basic biology. The lack of life history information is partially attributed to the difficulty in obtaining samples and is compounded by a lack of methods to appropriately assess traditional life history parameters, such as age and growth. To better understand the life history of this species, genetic techniques were used to examine its mating system and to assess whether an alternative ageing method could be developed. The use of microsatellite markers to examine the mating system showed that polyandry was present in $33 \%$ of the litters. However, the frequency of multiple paternity and its comparison to other aspects of the breeding biology of this species do not fit within the usual elasmobranch paradigms. The use of qPCR to measure telomere length showed that telomeres appear to shorten with increased length $(\mathrm{p}=0.0007)$. Though more work will need to be done to develop this as an ageing method, it may help to develop understanding of elasmobranch life history outside of traditional parameters. 


\section{ACKNOWLEDGMENTS}

I greatly thank all of the organizations that financially contributed to the successful completion of my thesis and the presentation of my findings at conferences which included Moss Landing Marine Laboratories (MLML) (Wave Award), Dr. Earl H. Myers and Ethel M. Myers Oceanographic and Marine Biology Trust, CSU COAST, and the American Elasmobranch Society.

I thank my thesis committee, Dr. David Ebert, Dr. Scott Hamilton, and Dr. Kenneth Coale for all of your invaluable feedback on my thesis and each of your unique approaches in fostering my academic growth. I am grateful for your investment in me to ensure my success as a graduate student and your perspectives and guidance that have and will continue to contribute to my professional and personal development. I appreciate it more than I can express.

I thank my collaborators, Dr. Alexis Janosik, Rebecca Varney, and Dr. Kevin Feldheim for each your contributions to the success of my thesis and furthering my knowledge base. Thank you, Rebecca, for your friendship and guidance through a new area of study to me and for your unwavering moral compass. Thank you, Kevin, for your mentorship, support, kindness, and patience and willingness to answer my never-ending questions. Your involvement in my thesis was transformative and for that I am forever grateful.

Thank you to everyone at MLML. This institution has made a lasting impression on me and the things I have learned and experiences I have had I will take with me always. A special thank you to my lab mates at MLML in the Pacific Shark Research Center and 
in the greater ichthyology lab. Help was always given when it was asked for and I am happy to have had such an amazing group of people to go through graduate school with.

To my friends both at MLML and beyond, I am incredibly lucky to have your support and friendship. It took a team to get me through to the other side, and I am so honored to have you all on mine. To my family, thank you for your lifelong support and encouragement to pursue my chosen career path. Thank you to my sisters Stephanie and Angela for never getting too upset when I had to miss an event or birthday due to my travels for school or needing to write my thesis. And last, but not least, I thank my dad for always being my biggest cheerleader. You have taught me so much about the type of person I want to be and how to apply hard work and compassion to all aspects of my life. You have taught me to always find the silver lining, especially when I found it hard to find it myself. Thank you for always believing in me. 


\section{Table of Contents}

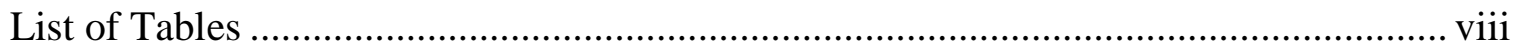

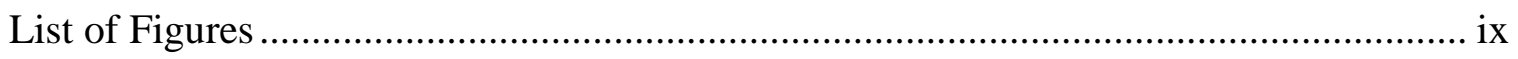

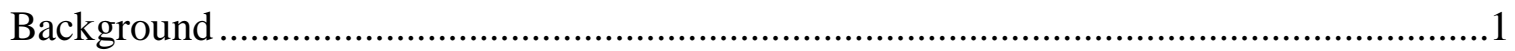

Chapter One: Understanding What We Cannot See: A Genetic Approach to the Mating System of The Southern Lanternshark, Etmopterus granulosus ................................6

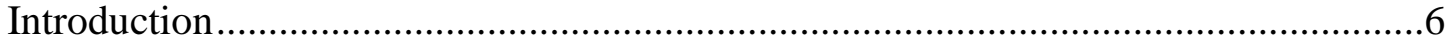

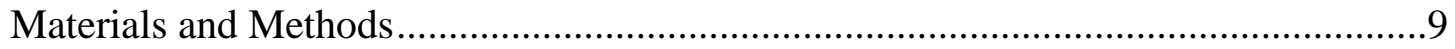

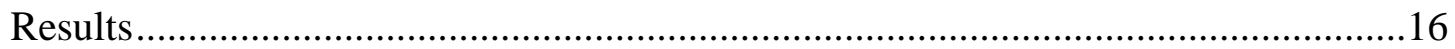

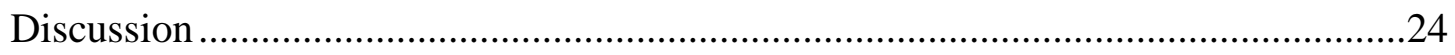

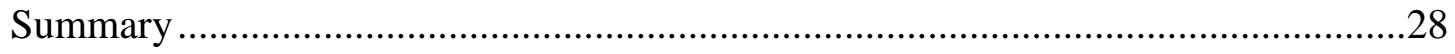

Chapter Two: Telomere Length and Longevity: An Exploratory Study Using the Deep-

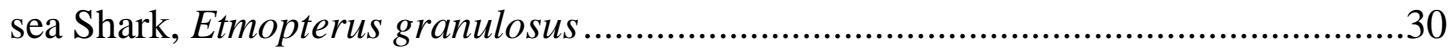

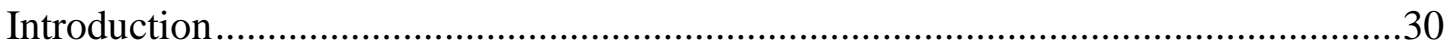



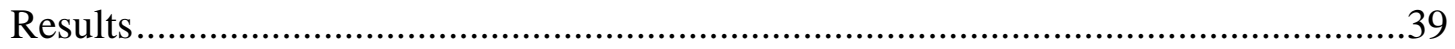

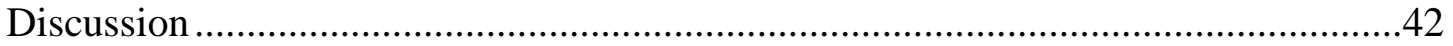

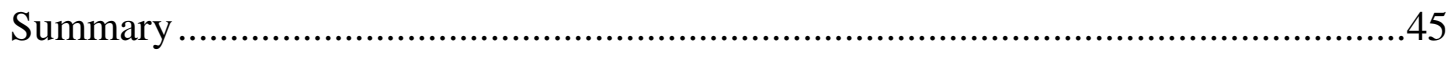

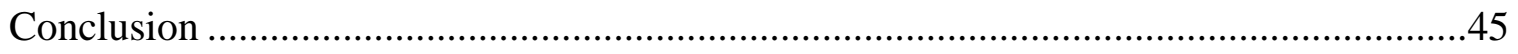






\section{List of Tables}

Table 1. PCR Information for Each Locus ..............................................................14

Table 2. Summary Statistics for All Microsatellite Loci Amplified from Etmopterus

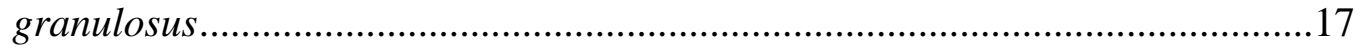

Table 3. Results from Paternity Reconstruction ..................................................18

Table 4. STORM Results from Internal Relatedness Analysis......................................20

Table 5. Compilation of Multiple Paternity Studies in Sharks (Study Species in Bold) ...27

Table 6. Examples of Methods for Band Enhancement with References........................31

Table 7. Examples of Methods Used for Validation and Verification in Ageing Studies.32 


\section{List of Figures}

Figure 1. Dorsal View of Etmopterus granulosus....................................................

Figure 2. Map of the Sampling Locations ...............................................................10

Figure 3. Individuals Displayed on the Map are Ones that Showed IR Values...........19

Figure 4. Examples of the Discrepancy of Gestational Stages and Embryonic Development ..........................................................................................

Figure 5. Mom TL Plotted Against Litter Size ....................................................22

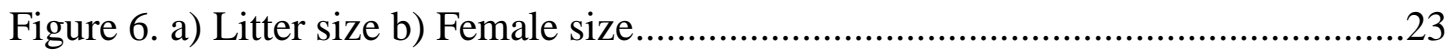

Figure 7. Relationship Between Ct and Total Length..................................................39

Figure 8. Pups from the litter depicted in circles have a larger spread in Ct values ....40

Figure 9. Comparison of Sex, Gravid Females, Males and Pups ................................41 


\section{Background}

In a post-World War II era, where technological advancements had been made and protein supply was limited, nations finally had the ability and necessity to create a fishing vessel that would allow them to explore fishing grounds well outside their normal range (Dietrich and Wulf-Heinrich, 1995). Before the 1950s, the distance from land fishing vessels could operate was limited to ensure their catch did not spoil. The invention and use of factory-freezer trawlers allowed vessels to traverse ocean basins, explore new fishing grounds, and remain at sea for extended periods of time (Strohbusch, 1967).

Increased time at sea, meant more fishing grounds were being discovered and the desire to increase fishing effort on these newly discovered areas led the creation of factory-freezer fleets, such as those employed by the Soviet Union (U.S.S.R.) in the mid1950s (Heidbrink, 2011). The U.S.S.R. spread their fleet throughout the world's oceans, including fishing within the Southwestern Indian Ocean (SWIO) beginning in 1964, with consistent, heavy fishing beginning in the 1970s, using trawl gear as one of their main fishing types. Though the U.S.S.R. never targeted Orange Roughy (Hoplostethus atlanticus), the main targeted fish today, their presence in these waters and the species they caught, were the impetus for the present-day fishery that began in the mid 1990s (SIODFA, 2010).

A targeted fishery for Orange Roughy had already developed in Australian and New Zealand waters beginning in the 1980s. Through this fishery, it became common knowledge that these fish associated with bathymetric features of high relief, such as seamounts and ocean ridges. The fishery subsequently expanded to the SWIO where the 
U.S.S.R. had previously fished on seamounts and ridges and by 2001 up to 53 fishing vessels flagged by 17 countries and states were participating in the fishery. By 2004, the fishing fleet in this region had been reduced to five vessels, largely attributed to a lack of understanding of the necessary equipment to fish the deep-sea and the unreliability of the quantity and location of the targeted species that most vessels lacked (Strutt, 2001). Stability of the fishery as of 2012, in the SWIO, would not exceed four vessels (Fishing in the SIO, 2010).

The stability of the fishery and its dependence on the limited number of vessels that can target Orange Roughy and other fish, such as Alfonsino (Beryx splendens), can be attributed to the life history of these deep-sea fishes. Though in-depth understanding of deep-sea species is typically restricted to those of high economic value, such as Orange Roughy, the available data suggest that slow growth, increased longevity, and late maturation are in varying degrees a part of their life histories (Cailliet, Andrews, Burton, $\&$ Watters, 2001). The understanding of this information is essential for the effectiveness of fisheries management, often leaving those that are frequently caught as bycatch and of little to no economic value, relatively understudied.

Chondrichthyans are typically of low economic value, leaving this class with little investment in research and management (Camhi, Fowler, Musick, Bräutigam, \& Fordham, 1998). This group of fishes are commonly caught as bycatch in the Orange Roughy and Alfonsino fisheries within the SWIO and share life history traits of slow growth, increased longevity, and late maturation with deep-sea teleosts. However, an 
added factor of low fecundity, when compared to their teleost counterparts, raises additional concerns about their resilience to fishing pressure.

Stevens, Bonfil, Dulvy and Walker (2000), highlights the necessity for adequate life history assessments of Chondrichthyans, a sentiment mirrored by Compagno and Musick (2005) as 50\% or more of cartilaginous fishes live in fished regions below $200 \mathrm{~m}$.

Additionally, many Chondrichthyans that live below these depths live on seamounts and other distinct geologic regions such as mid-ocean ridges (Priede et al., 2006). Such habitats lack species-specific and ecosystem level knowledge and have been categorized as vulnerable areas (Clark, Watling, Rowden, Guinotte, \& Smith, 2011). These inherent vulnerabilities and limitations of the deep-sea environment have presented challenges for regional fisheries governing bodies as the management regimes often operate at low levels of species-specific knowledge coupled with taxonomic confusion (FAO, 2009).

The Southern Lanternshark, Etmopterus granulosus is among the species that have undergone taxonomic revisions within recent years. Straube et al. (2015) clarified the taxonomic status of Etmopterus granulosus, by concluding that it is a senior synonym of Etmopterus baxteri (Garrick, 1957), synonymizing the two species into E. granulosus. Until taxonomic clarification, it was not possible to accurately assess this species and the potential threats to its local and global populations. Currently E. granulosus is categorized as "Least Concern" in the IUCN Red List Assessment, based on the available information (Finucci \& Lamilla, 2018). However, little information is known about the life history of this species or how population seizes may have changed over time in response to fishing activities in the SWIO. 
Etmopterus granulosus (Günther, 1880), is a relatively small shark with a maximum size of $<100 \mathrm{~cm}$ total length (TL) that is widely distributed throughout the Southern oceans. It inhabits upper slopes, seamounts and ridges from 220-1500 m depth, commonly found around $600 \mathrm{~m}$. Due to its depth distribution, it is frequently a source of bycatch in the Orange Roughy and Alfonsino fishery in the SWIO. One recorded estimate from the Orange Rough fishery on the northeast Chatham Rise estimated that a 26\% population decline of E. granulosus occurred between 1986 and 1994 (Clark, Anderson, Francis, R.I.C.C. \& Tracey, 2000). Yet, other than this single record, the large numbers of E. granulosus caught as bycatch does not appear to be causing a reduction in the presence and abundance of the species (Brit Finuci, NIWA, pers comm). High resilience of deep-sea species to fishing pressure is unlikely, given their life history traits (Simpfendorfer \& Kyne, 2009; Kyne \& Simpfendorfer, 2010), and thus the apparent stability of populations to fishing pressure may simply reflect that the knowledge of this species is data-limited.

Ageing data suggest that E. granulosus may live as long as 57 years with age at maturity estimated to be around 20 years for males and 30 years for females (Irvine, Stevens \& Laurenson, 2006; Ebert, 2015). There are regional differences in the size at maturity, where males mature at $46-68 \mathrm{~cm}$ TL and females mature at $62-69 \mathrm{~cm}$ TL, with size at birth around 17-20 cm TL (Ebert et al., 2013). Reproduction in Etmopterus granulosus is classified as lecithotrophic viviparous and the species is presumed to have asynchronous reproduction. This reproductive mode has yet to be verified and a reproductive cycle has not yet been established. The understanding of both of these 
factors would be useful in broadening the understanding of the mating system of $E$. granulsous.

Irvine et al. (2006) noted a discrepancy between internal and external banding of dorsal fin spines when used for ageing, creating uncertainty about which method is more accurate for this species. Harry (2017) and Natanson et al. (2018) provided evidence that a large proportion of elasmobranch ageing studies are flawed, with systemic issues of under-ageing and a distinct lack of validation and verification. Given this information, all age-related data are taken as an estimate, but currently the best option available for this species.

The goal of this study is to examine the mating system of Etmopterus granulsous using morphological and genetic data from gravid females and their pups, a combined approach that has not broadly been used to assess reproduction in elasmobranchs. Additionally, the continued uncertainty with ageing in elasmobranchs (Natanson et al., 2018), and the problems this presents to fisheries management, call for alternative ageing methods. This study used telomere length to assess biological rather than chronological age. The overall objective is to provide information that will create a better baseline understanding of the life history and mating system of E. granulosus with hopes of developing better management in this region. Lastly, this study hopes to provide a catalyst for more creative approaches to elasmobranch research, shifting away from dogmatic practices and to challenge traditional paradigms. 


\section{Chapter One: Understanding What We Cannot See: A Genetic Approach to the Mating System of The Southern Lanternshark, Etmopterus granulosus}

\section{Introduction}

The use of genetic techniques has revolutionized how we view the natural world. The most classic example of which is the ornithological paradigm of monogamy (Lack, 1968) that was dismantled with the use of DNA analysis (Westneat, 1990; Dixon, Ross, O’Malley \& Burke, 1994; Birkhead \& Møller, 1995). Since then, countless other studies have used genetic techniques to examine mating systems in everything from fungi to vertebrates. In studies on elasmobranchs, however, the field has lagged behind other vertebrate lineages. One of the first studies to employ DNA to examine the mating system of a shark only examined a single litter (Feldheim et al., 2001). Despite progress in using genetic techniques to examine population structure, reproduction, and conservation genetics (Dudgeon et al., 2012), the understanding of mating systems within elasmobranchs is still limited.

The majority of mating system studies on elasmobranchs have employed microsatellite markers, highly polymorphic short tandem repeats of one to 10 base pairs, allowing researchers to obtain a genetic fingerprint of each individual analyzed. Few elasmobranch studies have large enough sample sizes for an in-depth analysis of the mating system of any species. The handful of studies that have large sample sizes conclude that the trend for elasmobranchs is that mating is polyandrous with female sharks mating with multiple males. The reason for this behavior remains unknown, but one hypothesis that has been proposed for sharks is convenience polyandry (Portnoy et al., 2007; DiBattista, Feldheim, Gruber \& Hendry, 2008a) whereby females accept 
matings from aggressive males to avoid harassment. Lyons et al. (2017), examined the relationship between physical characteristics of males and females and polyandry in the round stingray (Urobatis halleri). This study was able to conclude that post-copulatory female mediation via ovulation pattern between uteri was likely used to limit a male's access to eggs and to increase rates of multiple paternity. This offers an alternative perspective that polyandrous behavior may be in some way beneficial to enhance genetic diversity that and multiple paternity an intended outcome to increase offspring fitness.

To understand if observed frequencies of multiple paternity are attributed to harassment avoidance, or a genetically favorable result that increases offspring fitness, further investigation is needed. One way to do this may be to compare the genetic mating system to other life history factors that may help reconstruct behavior of the species such as relationships between female size/age and paternity (e.g. sperm storage), or drivers of sexual selection (e.g. post-copulatory sexual selection) (Pearse, Janzen \& Avise, 2001; Birkhead \& Pizzari, 2002). This information may help to create an understanding of which individuals within a population are more vulnerable to anthropogenic influence, such as larger, more fecund females. Furthermore, making inferences about reproductive behavior based on indirect data may be the only currently feasible option for understanding mating systems of species that reside within the deep-sea.

The deep-sea Southern Lanternshark, Etmopterus granulosus (Günther, 1880) (Figure 1), inhabits upper slopes, seamounts and ridges from 220-1500 m depth. 


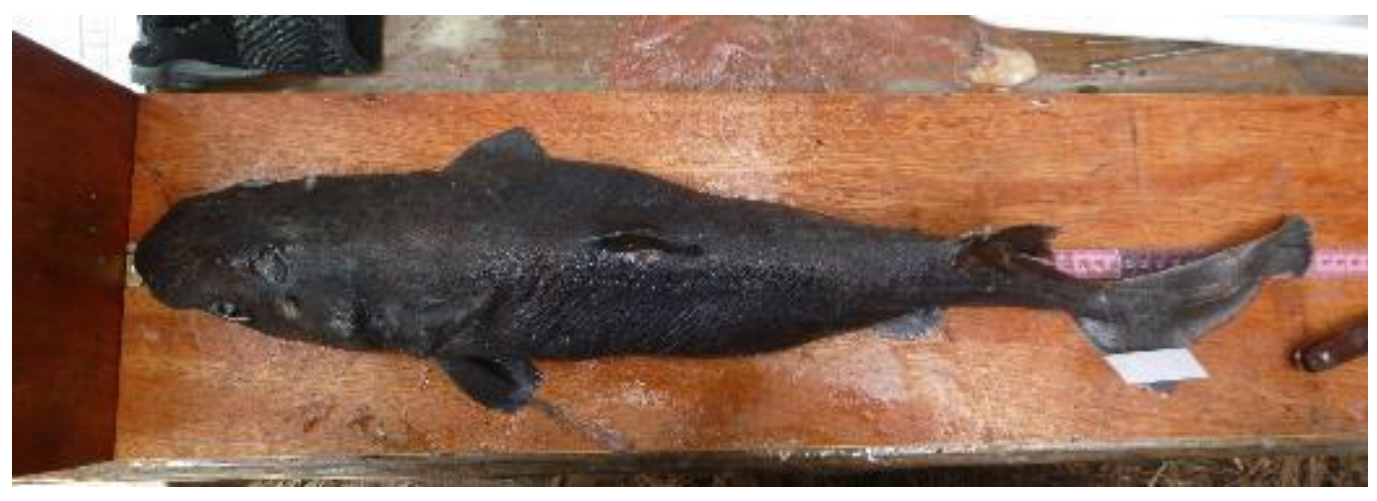

Figure 1. Dorsal view of Etmopterus granulosus.

It reaches a maximum size of $<100 \mathrm{~cm}$ total length and is yolk-sac viviparous with litters of 5-16 pups. It is common throughout the southern oceans and is frequently a source of bycatch in the Orange Roughy (Hoplostethus atlanticus) and Alfonsino (Beryx decadactylus) fisheries in the Southwest Indian Ocean (SWIO). Outside of basic biological and habitat information, little is known about E. granulosus, making it difficult to assess the accuracy of the paradigms we have established on the reproductive biology of sharks and other deep-sea organisms, and how they may apply to this species.

Currently, the International Union for the Conservation of Nature (IUCN) has listed E. granulosus as a species of least concern (Finucci \& Lamilla, 2018). However, without appropriate multi-year data, we cannot be sure if this is an accurate assessment of the current status and population trends of a species that is so frequently caught incidentally in deep-sea trawl fisheries. The lack of robust data considering the abundance and widespread species' distribution within the southern oceans is concerning. Additionally, its perceived persistence despite fishing pressure makes E. granulosus an interesting species to investigate. 
The goal of this study is to better understand the mating system of E. granulosus, using species-specific microsatellite markers. The use of microsatellite markers provides high enough resolution to distinguish between individuals, allowing for an assessment of the type of mating employed by E. granulosus. Additionally, these markers are useful to examine the effects of fishing on population structure and whether the mating system is influences genetic diversity of this species. Using morphological and genetic data of mothers and their offspring - such as the size of the female, litter size, and any variation in pup size, within and between litters, and the comparison to paternity results - may help to infer behavioral trends of reproduction. With the combination of these factors several aspects of the breeding biology of this elusive shark are examined.

\section{Materials and Methods}

Etmopterus granulosus specimens were obtained as bycatch from benthic and midwater trawls by the F/V Will Watch, a Cook Islands flagged commercial fishing vessel that operates out of Port Louis, Republic of Mauritius. The fishing grounds are in the SWIO along the Madagascar Ridge, Walter's Shoal, and Southwest Indian Ridge (Figure 2). 




Figure 2. Map of the sampling location is along the Madagascar Ridge, Walter's Shoal, and Southern Indian Ridge.

Bycaught specimens were frozen upon capture, and brought to Albion Fisheries Center in Albion, Mauritius where they were processed. Total length, measured to the nearest millimeter (mm), and overall body condition were recorded. Muscle tissue samples (stored in 95\% EtOH) were taken from 35 adult male and female E. granulosus as representative population samples, presumed to be unrelated. Total length of adult female E. granulosus were taken and uteri inspected to determine reproductive state. Gravid females were retained, the left and right uteri were extracted, and number the of pups per female recorded. Position (relative to genital canal and ovary), TL, and sex (when possible) of each pup were recorded. Muscle tissue samples were collected from 18 gravid females and their 146 pups and stored in 95\% EtOH until brought back to Moss 
Landing Marine Laboratories, Moss Landing, California, USA for processing and DNA extraction.

Specimens collected as unrelated population representatives were collected between March to May in 2012 and April to June in 2014. Gravid females were collected in both years, however due to storage complications, only samples from 2014 were usable. Gravid female size ranged from $695 \mathrm{~mm}$ to $805 \mathrm{~mm}$, all in good body condition with no visible wounds, trauma or parasite load. Females were caught at varying gestational stages and the fetal size ranged from $30 \mathrm{~mm}$ to $208 \mathrm{~mm}$. The unrelated individual samples were comprised of seven sexually mature males ranging from 490-780 mm TL, and 28 females ranging from 690-910 mm TL.

DNA was extracted from each individual using a Qiagen DNeasy Blood and Tissue Kit (Qiagen, Valencia CA) following the manufacturer's protocol to be used in paternity analysis and microsatellite marker development. DNA from two individuals was used to develop novel species-specific microsatellite markers. Microsatellite marker development followed an enrichment protocol (Glenn \& Schable 2005). DNAs were digested with RsaI and XmnI, and SuperSNX24 linkers were ligated onto the ends of gDNA fragments. Linkers act as priming sites for polymerase chain reactions (PCR) in subsequent steps. Three sets of probes: tetranucleotides $\left[(\mathrm{AAAT})_{8},(\mathrm{AACT})_{8},(\mathrm{AAGT})_{8},(\mathrm{ACAT})_{8}\right.$, $\left.(\mathrm{AGAT})_{8}\right]$, trinucleotides $\left[(\mathrm{ACT})_{12},(\mathrm{ATC})_{8},(\mathrm{ACG})_{6},(\mathrm{AAC})_{6},(\mathrm{AAG})_{8},(\mathrm{AGC})_{6}\right]$, and dinucleotides $\left[(\mathrm{TG})_{12},(\mathrm{AG})_{12}\right]$, were hybridized to gDNA in three separate reactions. These complexes were added to magnetic beads coated with steptavidin (Dynabeads ${ }^{\circledR}$ M-280 ThermoFisher Waltham, MA). Mixtures were washed twice with 2xSSC, $0.1 \%$ 
SDS and four times with $1 \mathrm{xSSC}, 0.1 \% \mathrm{SDS}$ at $52{ }^{\circ} \mathrm{C}$. Enriched fragments were removed from the biotinylated probe by denaturing at $95{ }^{\circ} \mathrm{C}$ and precipitated with $95 \%$ ethanol and $3 \mathrm{M}$ sodium acetate. A "recovery" PCR was performed in a $25 \mu 1$ reaction containing $1 \mathrm{X}$ PCR buffer (10mM Tris-HCl, 50mM KCl, $\mathrm{pH} 8.3), 1.5 \mathrm{mM} \mathrm{MgCl} 2,0.16 \mathrm{mM}$ of each dNTP, 10X BSA, $0.52 \mu \mathrm{M}$ of the SuperSNX24 forward primer, $1 \mathrm{U}$ Taq DNA polymerase, and approximately $25 \mathrm{ng}$ enriched gDNA fragments. Thermal cycling in a C1000 touch (Bio-Rad, Hercules, CA), was performed as follows: $95{ }^{\circ} \mathrm{C}$ for $2 \mathrm{~min}$ followed by 25 cycles of $95{ }^{\circ} \mathrm{C}$ for $20 \mathrm{~s}, 60^{\circ} \mathrm{C}$ for 20 s, and $72{ }^{\circ} \mathrm{C}$ for 90 s, and a final elongation step of $72{ }^{\circ} \mathrm{C}$ for $30 \mathrm{~min}$. Subsequent PCR fragments were cloned using the TOPO-TA Cloning $®$ kit following the manufacturer's protocol (ThermoFisher). Bacterial colonies containing a vector with gDNA (i.e. white colonies) were used as a template for subsequent PCR. These PCR products were cleaned using ExoSAP-IT (ThermoFisher), and DNA sequencing was performed using the BigDye ${ }^{\circledR}$ Terminator v3.1 Cycle Sequencing Kit (ThermoFisher). Sequencing reactions were precipitated with ethanol and 125mM EDTA and run on an ABI 3730 DNA Analyzer. From this enrichment, we developed 62 primer pairs that were used on the 35 unrelated individuals to test for polymorphism. Of these, ten were found to amplify consistently and were variable, and used to genotype all individuals.

Polymerase chain reaction (PCR) was completed using $10 \mu$ reactions consisting of 1U Taq polymerase, $0.12 \mathrm{mM}$ of each dNTP, 1x PCR Buffer, 1.5-2.5 mM Magnesium Chloride $\left(\mathrm{MgCl}_{2}\right), 10 \mathrm{x}$ BSA, $0.04 \mu \mathrm{M}$ Forward Primer, $0.16 \mu \mathrm{M}$ Reverse Primer and of a fluorescently labeled universal M13 primer, and $1 \mu 1$ DNA of varying concentrations. 
The 5' end of each forward primer had a universal M13-tail to allow labeling with fluorescent M13 primers with one of four dyes, VIC, 6-FAM, PET, or NED (Schuelke, 2000). PCR conditions were optimized for each primer set using a temperature gradient and the addition of $\mathrm{MgCl}_{2}$ to $2.5 \mathrm{mM}$. All individuals were then run with optimized PCR conditions for each locus (Table 1). Fluorescently labeled PCR products were run for fragment analysis on an ABI PRISM 3730 Genetic Analyser and scored using a custom ladder, ALEXA-725 (Maddox and Feldheim, 2014) in the microsatellite plug-in of Geneious.

MatLab was used after the scored loci were exported from Geneious to combine all loci files and format them for use in analytical programs. One adult was removed from analyses due to lack of amplification at more than half of all loci, reducing the population individuals to 34. Expected and observed heterozygosity, allelic diversity, linkage disequilibrium, and Hardy-Weinberg Equilibrium (HWE) were all examined with GenePop (v.4.7.0; Raymond \& Rousset, 1995; Rousset, 2008) under Markov chain parameters of 700 dememorization steps, 900 batches, and 1,000 iteration per batch. 
Table 1.

\section{PCR Information for Each Locus.}

\begin{tabular}{|c|c|c|c|c|c|c|c|}
\hline Locus & Primer sequence 5' to 3' & $\begin{array}{l}\text { Dye } \\
\text { Label }\end{array}$ & $\mathrm{T}_{\mathbf{a}}\left({ }^{\circ} \mathrm{C}\right)[$ & $\left.\mathrm{MgCl}_{2}\right]$ & $\begin{array}{l}\text { No. } \\
\text { Alleles }\end{array}$ & Size Range & Repeat \\
\hline 74 & $\begin{array}{l}\text { F: TGTAAAACGACGGCCAGT GCTGCACTAATCTCGGGAGA } \\
\text { R: GTGTCT TACCAACTATCAGTCTGTTGTCT }\end{array}$ & VIC & $55^{\circ}$ & 2.5 & 30 & $335-458$ & (GATT)4...(AGAC)6 \\
\hline 255 & $\begin{array}{l}\text { F: TGTAAAACGACGGCCAGTAGCTGCACTAATCTCGGGAG } \\
\text { R: GTGTCTTACCAACTATCAGTCTGTTGTCTAT }\end{array}$ & PET & $58^{\circ}$ & 2.5 & 29 & $336-460$ & $(\mathrm{GATT}) 16 \ldots(\mathrm{AGAC}) 6$ \\
\hline 284 & $\begin{array}{l}\text { F: TGTAAAACGACGGCCAGTTCCCTTGCCTTGTTAACCCTT } \\
\text { R: GTGTCTTGCAACACCGGTCGATACCTT }\end{array}$ & PET & $58^{\circ}$ & 2.5 & 18 & $298-366$ & $\begin{array}{l}(\text { CATCA }) 2 \ldots 2 \\
(\text { AATTC }) 2\end{array}$ \\
\hline 303 & $\begin{array}{l}\text { F: TGTAAAACGACGGCCAGTGGGCGAAGGGACCATTTACT } \\
\text { R: GTGTCTTGGGAAAGTTGGGCGAGAAGA }\end{array}$ & VIC & $\begin{array}{l}\text { TD to } \\
55^{\circ}\end{array}$ & 1.5 & 20 & $210-271$ & $(\mathrm{CT}) 12,(\mathrm{CT}) 4$ \\
\hline 404B & $\begin{array}{l}\text { F: TGTAAAACGACGGCCAGACTTCATTTACTAGCTAAGTTGGGT } \\
\text { R: GTGTCTTCCAGAAAAGATCTATCAACATCAGGA }\end{array}$ & 6-FAM & $60^{\circ}$ & 2.5 & 16 & $217-260$ & (TTC) 15 \\
\hline 418 & $\begin{array}{l}\text { F: TGTAAAACGACGGCCAGT TGGCTGTAGAAGGGGACAGA } \\
\text { R: GTGTCTTAACCAACTGAACCACTGGGG }\end{array}$ & PET & $58^{\circ}$ & 2.5 & 9 & $300-340$ & (TCTT)3, (CTTC)13 \\
\hline 614 & $\begin{array}{l}\text { F: TGTAAAACGACGGCCAGT ATTGGATCACAGGTTATGGG } \\
\text { R: GTGTCTCACCCTGTACAGAGTCTGCA }\end{array}$ & 6-FAM & $61^{\circ}$ & 2.5 & 18 & $152-195$ & $\mathrm{CT}(13)$ \\
\hline 649 & $\begin{array}{l}\text { F: TGTAAAACGACGGCCAGT CGCGTTGTGGGCCTAATTTC } \\
\text { R: GTGTCTTCCAAAAACAGTCCTCCAGGG }\end{array}$ & PET & $59^{\circ}$ & 2.5 & 39 & $252-466$ & $(\mathrm{AGAC}) 8 . .(\mathrm{ACAG}) 11$ \\
\hline 659 & $\begin{array}{l}\text { F: TGTAAAACGACGGCCAGT TCTGTGGTTGGCAAGATGTT } \\
\text { R: GTGTCTTGTACATTGTCAAAGAATCGCT }\end{array}$ & NED & $60^{\circ}$ & 2.5 & 21 & $337-460$ & $(\mathrm{AGAC}) 19$ \\
\hline 675 & $\begin{array}{l}\text { F: TGTAAAACGACGGCCAGT ACGGTTGATACCATTCATGCC } \\
\text { R: GTGTCTACACTAACAGCCCTCAGTGC }\end{array}$ & PET & $60^{\circ}$ & 2.5 & 48 & $329-498$ & (AGAC)11 \\
\hline
\end{tabular}


GERUD (v.1.0; Jones, A. G. 2001), COLONY (v.2.0.6.4; Wang, 2004; Jones \& Wang, 2010), and manual reconstruction (Feldheim, Gruber \& Ashley, 2004) were used to construct paternal genotypes and infer the number of sires, conservatively assuming all sires are heterozygotes to avoid false inflation of multiple paternity. GERUD may underestimate the number of sires per litter and is run doing a pairwise comparison of allelic combinations and then pairwise comparisons of paternal allelic combinations to offspring until the program finds the most likely combination of paternal genotypes and the offspring they sired. COLONY is known to overestimate the number of sires and is run using a maximum likelihood method to assign parentage. Manual reconstruction was done for all litters to verify the allele combination assignments to the potential number of sires. Additionally, due to the large number of alleles at each locus, for one litter GERUD could not process the data and complete the analysis. Due to inconsistencies between the programs, the results of manual reconstruction were used for each litter to provide the most conservative estimate.

STORM (v.2.0; Frasier, 2008) is a program using Monte Carlo simulations to test the relatedness of each individuals' parents resulting in an Internal Relatedness (IR) value. The output values are from $0-1$, with zero indicating no relatedness and increasing values showing higher degrees of relatedness, to show the degree of inbreeding. Google Earth was used to create a map to visualize the distribution of individuals that showed IR values greater than 0.25 .

The statistical program JMP was used to run regressions of female size to litter size and logistic regressions were used to test the association of female size to paternity (as 
one or more sires), and paternity to litter size. The variance of pup TL from each litter, to control for the differences in gestational stages, was also run in a logistic regression against paternity. All factors for the logistic regression models were re-run using inputs from all three methods for determining paternity (GERUD, COLONY and manual reconstruction).

M-ratio (M) (Garza \& Williamson, 2001) simulates an equilibrium distribution based on population specific parameters loaded into the program that tests for a genetic bottleneck with parameters of $\theta=(1 / G)-1=3.98$, proportion of single step mutations $(1-$ Ps $=1-0.88)=0.12$, and delta-g $=2.8$. Critical-M $(\mathrm{Mc})$ was used to calculate the critical value at which a bottleneck would be observed under parameters of $n=152,8$ loci, theta $=3.98, \%$ larger mutations $=0.12$ mean larger mutation size $=2.8$. Parameters for $\mathrm{M}$ and Mc are reported for eight loci due to two loci out of Hardy-Weinberg equilibrium.

\section{Results}

GenePop results are summarized in Table 2. Loci were within Hardy-Weinberg equilibrium, except loci 675 and 649, likely due to the presence of null alleles. The number of alleles ranged from 9-48, with most loci exhibiting very high levels of diversity. No loci were found to be linked. Observed heterozygosity was consistently lower than expected heterozygosity at all loci. 
Table 2.

Summary Statistics for Microsatellite Loci Amplified from Etmopterus granulosus.

\begin{tabular}{ccccccc}
\hline Locus & $\mathbf{N}$ & $\mathbf{A}$ & Size Range & $\mathbf{H}_{\mathbf{O}}$ & $\mathbf{H}_{\mathbf{E}}$ & $\begin{array}{c}\mathbf{H W E} \\
\text { (p-value) }\end{array}$ \\
\hline 74 & 76 & 30 & $335-458$ & 0.8289 & 0.9056 & 0.0072 \\
255 & 76 & 32 & $336-460$ & 0.8553 & 0.9317 & 0.0077 \\
284 & 76 & 17 & $298-366$ & 0.7895 & 0.8760 & 0.0486 \\
303 & 76 & 22 & $210-271$ & 0.8553 & 0.9030 & 0.0232 \\
$404 \mathrm{~B}$ & 76 & 16 & $217-260$ & 0.7763 & 0.8662 & 0.0114 \\
418 & 76 & 9 & $300-340$ & 0.7237 & 0.7542 & 0.2099 \\
614 & 76 & 17 & $152-195$ & 0.7500 & 0.8400 & 0.0405 \\
649 & 76 & 38 & $252-466$ & 0.8158 & 0.9200 & $0.0017 *$ \\
659 & 76 & 21 & $337-460$ & 0.7763 & 0.8768 & 0.0182 \\
675 & 76 & 48 & $329-498$ & 0.7500 & 0.8962 & $0.0021 *$ \\
\hline
\end{tabular}

Note: For each locus, sample size $(N)$, number of alleles $(A)$, observed heterozygosity $\left(\mathrm{H}_{\mathrm{O}}\right)$, expected heterozygosity $\left(\mathrm{H}_{\mathrm{E}}\right)$, and Hardy-Weinberg Equilibrium (HWE) are provided. *Significant deviation from HWE after Bonferonni correction $(\alpha=0.005)$

Paternity results from both GERUD and manual reconstruction showed 6 of the 18 litters were due to multiple paternity. Interestingly, these six litters were not all the same between methods (Table 3). COLONY estimated 15 of the 18 litters were due to multiple paternity. We used the most conservative estimate of multiple paternity (i.e. manual reconstruction) for all subsequent analyses. Using this method, we found six of the 18 litters had two sires, and 12 had one sire (Table 3). 
Table 3.

Results from Paternity Reconstruction.

\begin{tabular}{|c|c|c|c|c|c|c|c|}
\hline Litter & $\begin{array}{l}\text { Mom } \\
\text { TL }\end{array}$ & $\begin{array}{c}\text { Mean Pup } \\
\text { TL }\end{array}$ & St. D & $\begin{array}{c}\text { Litter } \\
\text { Size }\end{array}$ & GERUD & COLONY & Manual \\
\hline 1 & 708 & 166.6 & 2.42 & 5 & 1 & 2 & 1 \\
\hline 2 & 730 & 163.375 & 6.08 & 8 & 2 & 2 & 1 \\
\hline 3 & 792 & 99.2 & 3.06 & 5 & 1 & 1 & 1 \\
\hline 4 & 725 & 109.75 & 1.56 & 8 & 1 & 2 & 1 \\
\hline 5 & 752 & 108.857 & 1.96 & 7 & 2 & 3 & 2 \\
\hline 6 & 740 & 109.75 & 3.27 & 8 & 2 & 2 & 1 \\
\hline 7 & 763 & 81.8 & 0.40 & 5 & 2 & 3 & 2 \\
\hline 8 & 805 & 65.615 & 4.12 & 13 & 3 & 2 & 2 \\
\hline 9 & 699 & 90.89 & 2.23 & 9 & 2 & 3 & 2 \\
\hline 10 & 745 & 99.57 & 1.92 & 7 & 1 & 2 & 1 \\
\hline 11 & 765 & 201.33 & 5.68 & 9 & 1 & 3 & 1 \\
\hline 12 & 780 & 32.57 & 1.50 & 14 & 1 & 2 & 1 \\
\hline 13 & 787 & 72 & 4.76 & 6 & 1 & 2 & 2 \\
\hline 14 & 715 & 56.9 & 1.97 & 10 & $*$ & 2 & 1 \\
\hline 15 & 695 & 101.71 & 2.12 & 7 & 1 & 3 & 2 \\
\hline 16 & 725 & 193.33 & 3.20 & 6 & 1 & 1 & 1 \\
\hline 17 & 740 & 76.57 & 1.50 & 7 & 1 & 1 & 1 \\
\hline 18 & 735 & 195 & 4.00 & 12 & 1 & 2 & 1 \\
\hline
\end{tabular}

Note: Shown are the litters, total length of the mother (Mom TL), mean pup total length (Mean Pup TL), standard deviation of pup length (St. D), litter size, and the estimated number of sires per litter using GERUD, COLONY, and manual reconstruction. The * notes where GERUD could not complete analysis. 
STORM showed relatively high internal relatedness in six adult females, three with parents related at the half-sibling level $(>0.25)$, one with parents related at the full-sibling level (>0.50), and two with parent-offspring mating $(>0.75)$. None of the individuals from the litters or their mothers exhibited signs of inbreeding $(<0.25)$. No trends were seen when individuals were plotted on a map by their catch location (Figure 3, Table 4), showing no geographic restrictions. M-ratio showed that no genetic bottleneck was detected $(M=0.83, M c=0.78)$. Though no statistical difference was seen between the inclusion of all ten loci and the use of eight loci, final numbers are reported with the parameters for eight loci to ensure validity of the numbers due to two loci out of HWE.

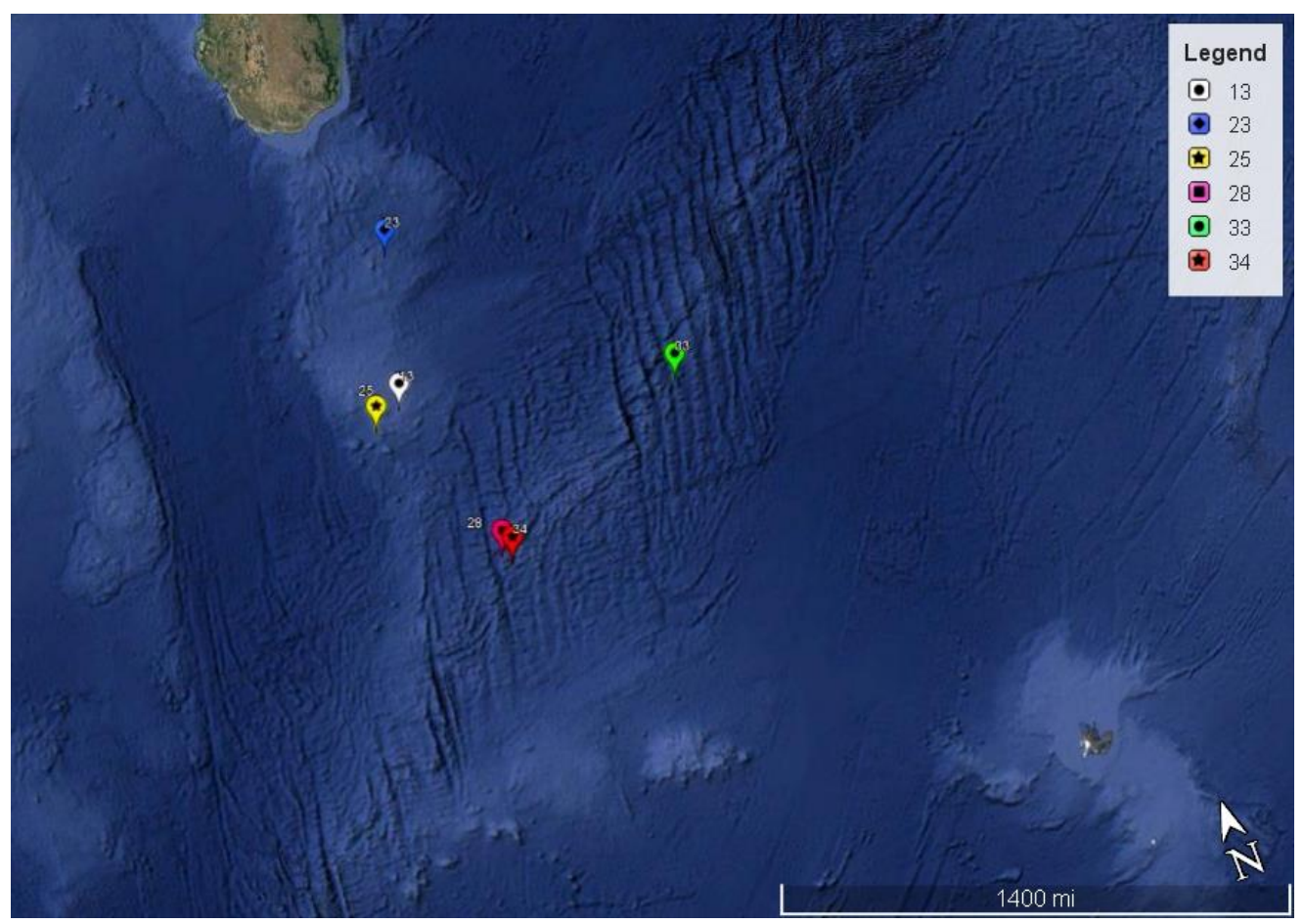

Figure 3. The individuals displayed on the map are ones that showed IR values. Three individuals had parents related at the half-sibling level $(>0.25)$, one with parents related at the full-sibling level (>0.50), and two with parent-offspring mating $(>0.75)$. 
Table 4.

STORM Results for Internal Relatedness Analysis.

\begin{tabular}{ccccc}
\hline Individual & IR-Value & Sex & $\begin{array}{c}\text { Total } \\
\text { Length }\end{array}$ & Date \\
\hline 34 & 0.457 & F & 82 & Mar-16 \\
33 & 0.323 & F & 81.3 & Mar-27 \\
28 & 0.783 & F & 73.1 & Mar-16 \\
25 & 0.348 & F & 80 & Mar-10 \\
23 & 0.519 & F & 76 & Mar-17 \\
13 & 0.764 & F & 69 & Mar-3 \\
\hline
\end{tabular}

Note: Values of 0.25-0.45 indicate parents of the individual are related at the half-sibling level, 0.5 to 0.74 indicate a full-sibling level relationship, and 0.75 and up could indicate parent-offspring mating.

All litters examined over the two-month collection period were at varying gestational stages from early embryonic development to full development with the yolk sac fully absorbed (Figure 4). Gravid females had embryos developing in both left and right uteri, with evidence of concurrent oocyte development during gestation, suggesting there is no or a short resting period post parturition. No differences in size of embryos between the left and right uterus were seen within litters and nor differences between the usage of the left and right uteri among litters (Left $=63$, Right $=70$ ), with the exception of one female that had four pups in her right uterus only. There was uncertainty of the uterine origin of 13 pups due to their position within the urogenital canal rather than within the uterus or the accidental removal of a pup from the uterus as the reproductive tract was being excised. Results from regression and logistic regression analyses showed no association between female size and litter size (linear regression, $F_{1,16}=0.72, r^{2}=0.04, p=0.41$ ) 
(Figure 5), and the y response of 1 or more sires and litter size (logistic regression $\left(\chi^{2}=\right.$ $0.68, \mathrm{p}=0.41$ ) and number of sires and female size (logistic regression, $\chi^{2}=0.38, \mathrm{p}=0.54$ ) (Figure 6). Lack of significance was consistent across all analyses regardless of paternity results used or any data transformation.

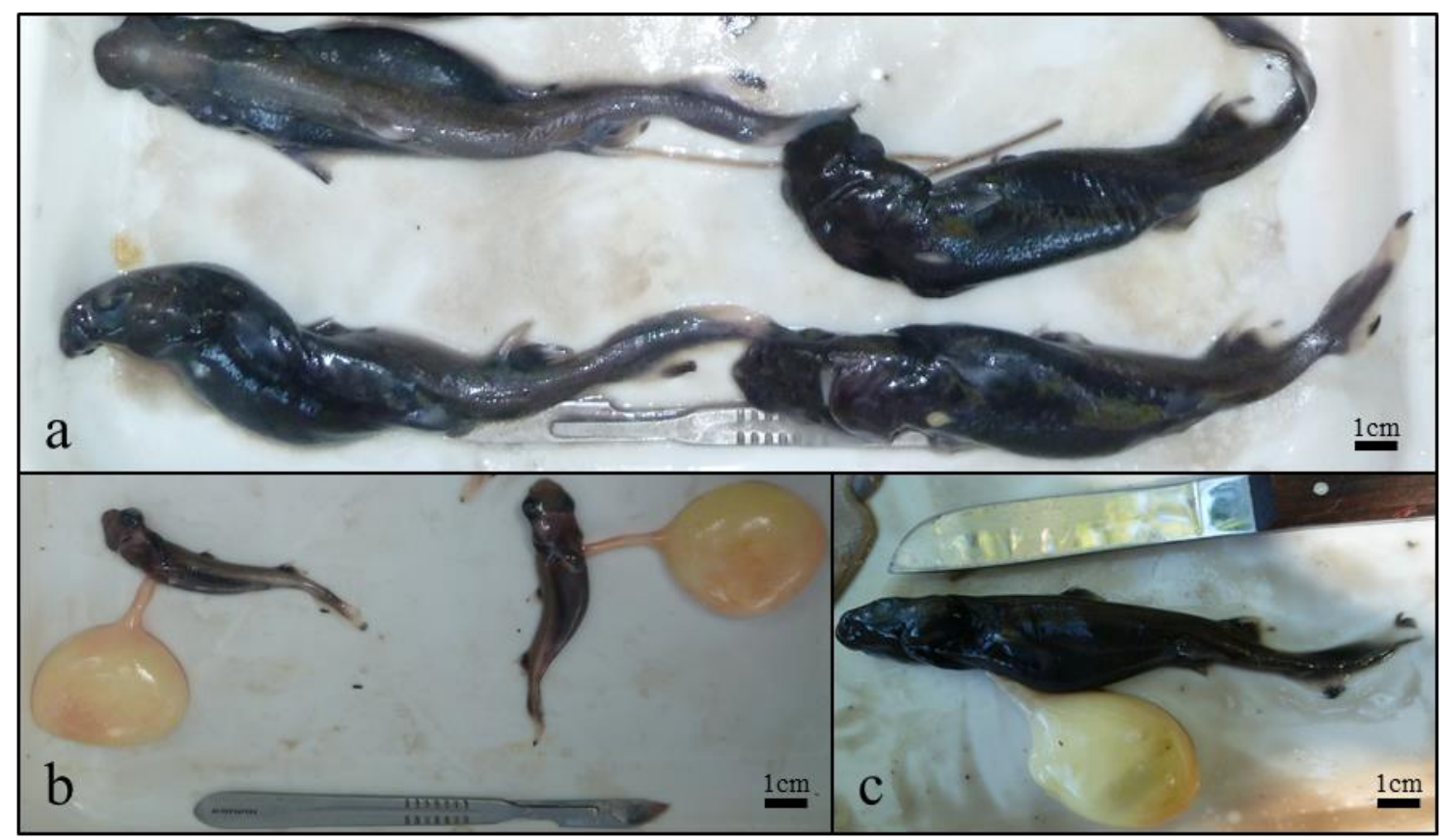

Figure 4. Examples of the discrepancy of gestational stages and embryonic development with a) fully developed and the yolk sac absorbed, b) early stage development with a large yolk sac and c) a more developed embryo with moderate yolk sac absorption. 


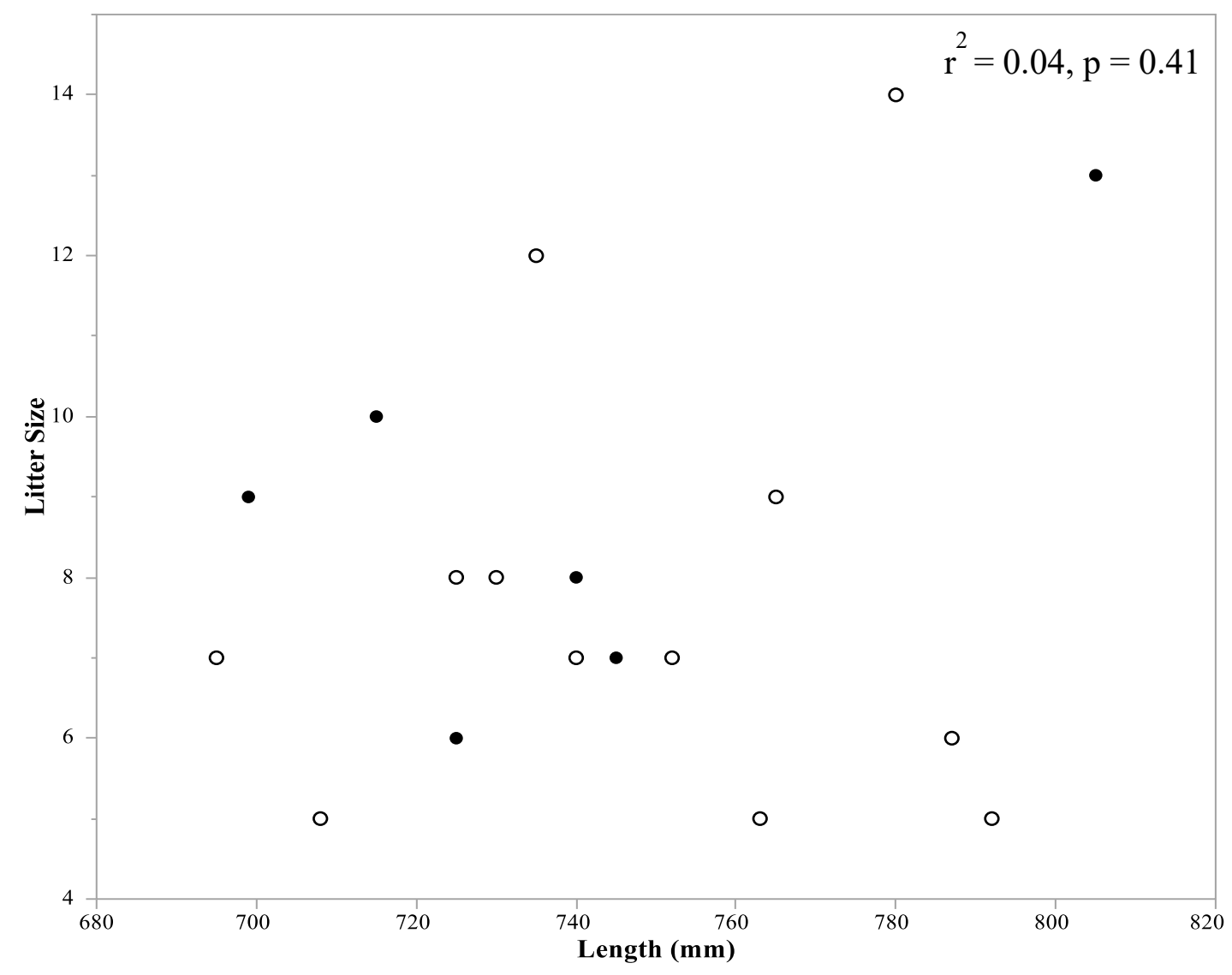

Figure 5. Gravid female TL plotted against litter size showing no statistical relationship between the two factors. The open circle represent litters with single paternity and the closed circles represent the litters with multiple sires. 



Figure 6. a) Litter size plotted against manually reconstructed paternity for each litter. $\left(\chi^{2}=0.68, p=0.41\right)$. b) Female size plotted against manually reconstructed paternity $\left(\chi^{2}=0.375381, \mathrm{p}=0.54\right)$. No association was seen between the size of the litter and the number of sires or female size and the number of sires. 


\section{Discussion}

This study examined the mating system of a deep-sea shark using microsatellite markers and found that Etmopterus granulosus females generally exhibit monogamy; however, the results also suggest that their mating system is likely dynamic, based on several factors. Aspects of the life history of this species suggest that mate availability may the limiting factor. A female skewed sex ratio and segregation by both size class and sex (Clerkin, 2017; Finucci, Dunn \& Jones, 2018) may contribute to monogamy by limiting access to viable mates. Asynchronous reproduction may also contribute to monogamy if the timing and/or location for this species to mate is inconsistent, therefore making it difficult to encounter a reproductively capable mate. Evidence of polyandry was found in only $33 \%$ of the litters examined here, despite it typically being the dominant mode of reproduction in elasmobranchs (DiBattista et al., 2008b).

Etmopterus granulosus, does not exhibit a significant association between female size and litter size. This may be attributed to multiple factors, but could be related to resource availability. Often, litter size is positively correlated with female size (Chapman, Prodohl, Gelsleichter, Manire \& Shivji, 2004), as available energy in larger females can be put into reproduction rather than growth. However, in the deep-sea environment prey resources are spare, patchily distributed, and unpredictable on a variety of spatial and temporal scales (Pitcher et al., 2007). Thus, for this species energy investment first in growth, then in reproduction may not increase the fitness of younger E. granulosus females if they are able to successfully carry larger litters. Therefore, reproductive output 
may be more closely associated with past feeding history and levels of energy reserves rather than female size.

Reproduction cycles are usually synced to external factors such as seasonality when prey availability may be higher. Many shark species follow this pattern (e.g. Carlisle, King, Cailliet, \& Brennan, 2007; Jirik \& Lowe, 2012; Baremore \& Passerotti, 2013) ensuring that the reproductive females have optimal conditions for gestation as well as for the offspring at the time of parturition. With Orange Roughy also exhibiting seasonal reproduction (Pankhurst, McMillan \& Tracey, 1987), this pattern is not limited to shallow environments. Etmopterus granulosus, however, does not seem to have a predictable reproductive cycle, potentially related to the more consistent environment of the deepsea, which lacks large seasonal differences. The extremes of embryonic development likely indicate different times of fertilization rather than natural variations in development if fertilization were to occur at the same time. Sperm storage is known to occur in all elasmobranch species in which it has been investigated (Maduna, Van Wyk, Da Silva, Gennari \& Bester-Van Der Merwe, 2018; Pratt, 1993), offering a reasonable explanation for the discrepancy in gestational development, particularly because it is unknown when and where they mate.

Etmopterus granulosus is known to segregate by both size class and sex, with individuals of all classes and sexes strongly associating with conspecifics (Finucci et al., 2018). This high degree of segregation is made even more interesting by the unequal sex ratio of 1:0.6 for adults in favor of females within the SWIO (Clerkin, 2017). If this ratio was only seen in adults, it might suggest that the males inhabit a different area or depth 
than where the females are being caught. However, Clerkin (2017) found that the juvenile sex ratio for this region is 1:0.5 in favor of females and the pup ratio is 1:0.65 in favor of females. The present study did not have the opportunity to observe this with only two litters developed enough to sex - one litter had five males and four females, and the other litter had 7 males and 4 females - yet, prior evidence likely indicates that within this region the sex ratio is naturally skewed. Finucci et al. (2018) found similar results, with an adult sex ratio of 1.1:1 in favor of females on the Chatham Rise and Campbell Plateau in New Zealand waters.

A female-biased sex ratio could limit the number of viable mates a female may encounter (Bateman, 1948). One way this could occur is through disproportionate mortality (e.g. fishing) between the sexes (Coelho, Fernandez-Carvalho, Lino \& Santos, 2012). Such a sex-biased reduction may lead to a subsequent genetic bottleneck. We found no such evidence of a bottleneck $(M=0.83, M c=0.78)$. Despite this, we found six of the 52 adults (11.5\%), had parents that were related (IR values >0.25), which supports either a limited number of mates, or a lack of inbreeding avoidance. It is not conclusive if this is due to a skewed sex ratio, or if movement of individuals is limited despite connectivity between bathymetric features in this region. Straube, Kriwet and Schliewen (2011), found E. granulosus to have low population differentiation between ocean basins demonstrating that gene flow between these large regions is possible, which suggests the observed frequency of inbreeding is not limited by mobility.

The frequency of inbreeding could also explain lower than expected heterozygosity across all loci tested, even with adequate allelic diversity. Null alleles were also present, 
contributing to lower than expected heterozygosity as well as to the observed loci out of HWE. Multiple mating can counteract inbreeding effects that could decrease genetic variability by ensuring the most fit, genetically diverse offspring (Stockley, Searle, Macdonald \& Jones, 1993). Yet, the observed frequency of multiple paternity in this species is $33 \%$, a lower value compared to other species on which paternity analyses have been conducted (Table 5). It would be predicted that the frequency of multiple paternity would be higher to ensure genetic diversity of the species, increasing its chances of surviving a catastrophic event (Cornell \& Tregenza, 2007; Taylor, Price, \& Wedell, 2014). However, moderate to high allelic diversity, despite low frequency of multiple paternity and lower than expected heterozygosity may mean that the cost of inbreeding is minimal. 
Table 5.

Compilation of Multiple Paternity Studies in Sharks (Study Species in Bold).

\begin{tabular}{|c|c|c|c|c|c|c|}
\hline Species & $\% \mathrm{MP}$ & $\begin{array}{c}\text { No. } \\
\text { Progeny }\end{array}$ & $\begin{array}{c}\text { No. } \\
\text { Litters }\end{array}$ & $\begin{array}{c}\text { Avg. Litter } \\
\text { Size (Range) }\end{array}$ & $\begin{array}{c}\text { No. } \\
\text { Sires/ } \\
\text { Litter }\end{array}$ & $\begin{array}{l}\text { No. } \\
\text { Loci }\end{array}$ \\
\hline $\begin{array}{l}\text { Carcharhinus } \\
\text { leucas }\end{array}$ & 50 & 33 & 4 & $8.25(5-11)$ & $1-2$ & 21 \\
\hline $\begin{array}{l}\text { Etmopterus } \\
\text { granulosus }\end{array}$ & 33.3 & 146 & 18 & $8.1(5-14)$ & $1-2$ & 10 \\
\hline Galeorhinus galeus & 40 & 145 & 5 & $29(23-34)$ & $1-3$ & 6 \\
\hline Mustelus henlei & 92.8 & 185 & 14 & $13.2(4-17)$ & $1-3$ & 4 \\
\hline Mustelus mustelus & 66.7 & 62 & 6 & $10(5-18)$ & $1-2$ & 6 \\
\hline $\begin{array}{l}\text { Negaprion } \\
\text { acutidens }\end{array}$ & 77.8 & 52 & 9 & $\mathrm{n} / \mathrm{a}$ & $\mathrm{n} / \mathrm{a}$ & 16 \\
\hline $\begin{array}{l}\text { Negaprion } \\
\text { brevirostris }\end{array}$ & 86.6 & 735 & 97 & $6.7(1-18)^{*}$ & $1-4$ & 9 \\
\hline Sphyrna lewini & 46.2 & 87 & 13 & $7(3-16)$ & $1-5$ & 5 \\
\hline Squalus acanthias & 17.2 & $\mathrm{n} / \mathrm{a}$ & 29 & 4-11 & $1-2$ & 7 \\
\hline Squalus acanthias & 30 & 50 & 10 & $5(3-7)$ & $1-2$ & 7 \\
\hline Squalus mitsukurii & 11.1 & 178 & 27 & $6.6(3-10)$ & $1-2$ & 8 \\
\hline
\end{tabular}

Note: Percent multiple paternity (\%MP), number of progeny, number of litters, average litter size with litter range, number of sires per litter, and number of loci are provided for comparison between studies. *denotes not full litters.

\section{Summary}

Despite the combined use of genetic and traditional life history parameters, this study has raised additional questions. Low heterozygosity, inbreeding, and low rates of multiple paternity in the absence of a genetic bottleneck seem conflicting. Irregularity in reproductive patterns may be beneficial to this species given that the larger females are not necessarily the most fecund. With an absence of a reproductive season, individuals may be able to reproduce year-round and be regularly fished without an extreme 
detriment to the population, as would be presumed. Without further investigation into reproductive and movement patterns, these results provide the best current understanding of this species' mating system.

It is important to note that information gathered through single species studies is vital to an ecosystem management approach. It cannot be taken for granted that species fit our preconceived understanding, as it could be either beneficial or detrimental to the species. Furthermore, among the elasmobranch species that have been tested for polyandrous behavior, all have exhibited some degree of multiple paternity. This shows that they have the capability, but additional information must be gathered to understand the drivers of the observed differences.

Future research would aim to increase sample sizes and sampling throughout the species' range to allow for a comparison of regional based differences, to assess if the results found in this study are consistent among global populations or if they are unique to the SWIO. Additionally, comparisons between populations from regions where Etmopterus granulosus are more regularly captured as bycatch and those in which they are not may help to address if the observed results in this study are due to fishing pressure in the SWIO, or if it is the natural state of this species. Etmopterus granulosus seems to provide a less conventional story in the elasmobranch paradigm, that warrants further investigation. 


\section{Chapter Two: Telomere Length and Longevity: An Exploratory Study Using the Deep-sea Shark, Etmopterus granulosus}

\section{Introduction}

Age assessment in elasmobranchs has a nearly century-long history (Kaganovskaya, 1933). Over this period of time, the majority of ageing studies have relied on calcified hard structures, despite inter- and intraspecific variability prohibitive to confident age estimates (Cailliet, 2015). Verification and validation are still under-utilized, despite the development and availability of several methods. Limitations, particularly sample size, and the subjective nature of ageing itself add to potential error. Age and growth estimates are fundamental metrics by which species assessments and management policies are developed. Alternative methods should be explored to accurately, precisely, and reliably age elasmobranchs.

Ridewood (1921) explored the composition and structure of vertebrae as a tool for ageing and identification of several species spanning most taxonomic groups of Chondrichthyans. He found inconsistencies within and among individuals of the same species, as well as variability between species, particularly with older specimens. He concluded that using vertebrae for taxonomic clarification or for ageing purposes was likely not useful. Additionally, Ridewood (1921) added that calcified masses within vertebrae were due to physiological demands, aligning with the function of the vertebral column as a support structure related to somatic growth and life history (Porter, Beltrán, Koob \& Summers, 2006).

Kaganovskaya (1933) examined Squalus acanthias, the Spiny Dogfish, dorsal fin spines as a method of ageing. He stated that the most important aspect of studying fish 
populations is age composition and growth to determine production potential. A determination of age using rings on dorsal spines was found, with the caveat that annual rings are very close together in larger individuals, making it difficult to determine age; a persisting issue in all ageing studies of long-lived elasmobranch species (Harry, 2018).

Haskell (1949) and Ishiyama (1951a, b) conducted the first ageing studies using vertebrae in sharks and skates, respectively. Popularity of using vertebrae for ageing grew, with a great amount of effort focusing on creating methods for band enhancement. One of the first methods used was histology (Ishiyama, 1951b) followed by various techniques including the use of several stains and radiography (Table 6). 
Table 6.

Examples of Methods for Band Enhancement with References.

\section{Method}

Alcohol immersion

Alizarin Red

Cedarwood Oil

Cobalt Nitrate/ Ammonium Sulfide

Copper, Lead and Iron salts

Crystal Violet

Decalcification (acid)

Graphite Microtopography

Grinding

Haemotoxylin

Histology

Injected Flourocrhome dyes

Microcomputed Tomography

Scanning X-ray Flourescense Microscopy

Silver Nitrate

$\mathrm{X}$-radiography

$\mathrm{X}$-ray spectrometry

Xylene Impregnation

\section{Author, year}

Richards et al, 1963

Lmarca, 1966; Gruber and Stout 1983

Cailliet et al, 1983a; Neer and Cailliet 2001

Hoenig and Brown, 1988

Gelsclighter et al, 1988a

Johnons, 1979; Schwartz, 1983

Correia and Figueiredo, 1997

Parsons, 1983 and 1985

Branstetter and Stiles, 1987

Tanaka and Mizue, 1979

Ishiyama, 1951; Casey et al, 1985

Officer et al, 1997

Geraghty et al, 2012

Raoult et al, 2016

Stevens 1975, Schwartz 1983

Aasen 1963

Jones and Green 1977, Casselman 1983

Daiber 1960

While using these methods, the necessity for validation and verification was realized.

Oxytetracycline injection and tag-recapture were one of the earliest methods used

(Holden \& Vince, 1973), providing strong validation if specimens could be recaptured.

Bomb radio carbon dating has gained popularity in recent years (Kalish, 1993), though a handful of other methods have also been developed (Table 7). 
Table 7.

Examples of Methods Used for Validation and Verification is Ageing Studies.

\begin{tabular}{|l|l|}
\hline Method & Author, year \\
\hline OTC & Holden and Vince 1973 \\
\hline MIA & Simpfendorfer 1993 \\
\hline CEA & Ishiyama, 1978; Tanaka et al, 1978 \\
\hline Bomb Radio Carbon & Kalish 1993 \\
\hline Tag re-capture & Holden and Vince 1973 \\
\hline Radiometric dating & Welden 1984, 1987 \\
\hline Site Fidelity/Philopatry & Brooks et al 2016 \\
\hline
\end{tabular}

Even with the recognized importance of validation and verification (Cailliet, Radtke \& Welden 1986; Cailliet 1990, 2004, 2015), many ageing studies fail to do either, and no study to date has validated age throughout a species' lifespan (Natanson et al., 2018). Furthermore, these methods require assumptions to be made about species without validation or verification; the most pertinent of which are band deposition periodicity, ontogenetic changes, and that young are born without band pairs. Squatina californica, the Pacific Angel shark, is an example of a species that breaks all of these assumptions (Cailliet, Martin, Harvey, Kusher \& Welden, 1983b; Natanson, 1984; Natanson \& Cailliet, 1986; Natanson \& Cailliet, 1990), information that would not have been known without validation and verification. Another example is Cetorhinus maximus, the Basking Shark, (Natanson et al., 2008) which was found to have well defined band pairs, yet, were not chronologically formed. These examples highlight current issues with ageing, as well as the dangers of dogmatic practices when conducting age and growth studies.

Shifting fishing effort and improved technology have allowed the deep-sea environment to become more accessible. With this, ageing studies have broadened to 
include deep-sea species. However, they offer a host of different physiological challenges to traditional ageing methods. Deep-sea elasmobranchs are often deficient in vertebral calcification, with near or complete absence of banding, rendering them unusable for ageing purposes. Dorsal fin spines are used as an alternative calcified structure for ageing, using the same method as Kaganovskaya (1933). However, dorsal fin spine erosion - breakage or wearing down - can make it difficult to obtain accurate band pair counts. Additionally, there are count discrepancies between internal versus external bands, further complicating age estimates with current practices (Irvine et al., 2006a).

Consistency is critical, but nearly impossible due to the inherent subjectivity of ageing. Reader experience, reader interpretation, computer screen, and imaging program selection are all factors of concern. Each can contribute to variability when ageing the same vertebrae from the same individual (Officer, Gason, Walker \& Clement, 1996; Natanson et al., 2018).

Even with original warnings from foundational papers in the field of elasmobranch ageing, and knowledge of current issues, advancements in ageing techniques have not come far enough to create consistently reliable working data. The field of study has advanced where possible: including consideration of multiple growth models to find the best fit (Pardo, Cooper \& Dulvy, 2013; Smart, Chin, Tobin \& Simpfendorfer, 2016) and attempts at using alternate structures (e.g. eye lenses in Nielsen et al., 2016). However, the shortcomings of current methods are well known, with a great need for new ageing methods, thus any additional metrics that can be added are of inherent value. 
One potential approach to improve ageing estimates for deep-sea elasmobranchs may involve the use of genetic data. Telomeres, DNA sequences at the ends of chromosomes, are known to shorten with age in diverse groups of eukaryotes (e.g. Haussmann, Winkler \& O’Reilly, 2003b). Rocco, Morescalchi, Costagliola, and Stingo (2002) assessed karyotypes and verified that the standard eukaryotic telomeric repeat (TTAGGG) is present in four cartilaginous species; Scyliorhinus canicula, Scyliorhinus stellaris, Raja asterias, and Taeniura lymma. Izzo, Bertozzi, Donnellan and Gillanders (2010), examined telomere length as a proxy for age, but found no correlation between telomere length and size. However, prior estimates of elasmobranch ageing make it clear that metrics are rarely consistent across all species. Given that the maximum lifespan, or longevity, of most sharks is unknown, elasmobranchs represent a unique system to investigate telomere dynamics.

Telomeres are known to shorten with ageing, but other factors can influence telomeric changes. Environment and habitat are known to impact telomere length (Haussmann \& Heidinger, 2015), however overall trends in telomere length in elasmobranchs must be determined before examination of environmental effects is possible. If telomeres shorten with age in a consistent manner, telomere length may provide an additional metric to estimate longevity, which may be useful for species that are difficult to age using traditional methods.

In the present study, we examined relative telomere lengths in a deep-sea squaloid shark the Southern Lanternshark. Etmopterus granulosus (Chondrichthyes: Squaliformes: Etmopteridae). This common and abundant species occurs broadly in the southern 
oceans, and inhabits waters from 220-1500 m depth on continental shelves and slopes, either on or near the bottom (Compagno, Ebert \& Smale 1989; Daley, Steven, Last \& Yearsley, 2002; Ebert, Fowler \& Compagno, 2013). A commercial fishery targeting primarily Alfonsino (Beryx decadactylus or B. splendens) and Orange Roughy (Hoplostethus atlanticus) catches Chondrichthyans in large proportions that are normally discarded as unwanted bycatch. This unwanted bycatch includes E. granulosus with representation of different size classes, sexes, and often, gravid females. The available samples through this fishery, depth of inhabitance, and the prolific nature of this species in southern waters, makes E. granulosus an ideal species for this study.

The aim of this study was to determine if there is any evidence of telomere shortening with age and if the degree of shortening correlates with the most common rough estimate for age (body length). Without a viable method for ageing elasmobranchs throughout any species' entire lifespan, alternative methods explored for ageing may provide the groundwork for future directions. Additionally, empirical age may not be as necessary if longevity cannot be obtained, and if indirect age information can be gathered through non-lethal methods.

\section{Materials and Methods}

Etmopterus granulosus specimens were obtained as bycatch from benthic and midwater trawls by the F/V "Will Watch," a Cook Islands flagged commercial fishing vessel that operates out of Port Louis, Republic of Mauritius. The fishing grounds are in the southwestern Indian Ocean along the Madagascar Ridge, Walter's Shoal, and 
Southwest Indian Ridge. The specimens obtained were collected during two separate trips from March to May in 2012 and April to June in 2014.

Specimens were frozen upon capture and brought to Albion Fisheries Center, Albion, Mauritius where they were thawed and processed. Total length (TL), measured to the nearest millimeter $(\mathrm{mm})$, and overall body condition were recorded. Muscle tissue samples (stored in 95\% EtOH) were taken from 35 adult male and female E. granulosus as representative population samples. Total length and body condition of adult female $E$. granulosus were taken and uteri inspected to determine reproductive state. Gravid females were retained and the left and right uteri extracted. The number, TL, position, and sex (when possible) of each pup was recorded from each uterus. Muscle tissue samples were collected from 18 gravid females and their pups and stored in 95\% EtOH and returned to Moss Landing Marine Laboratories, Moss Landing, California, USA. DNA was extracted from each female, pup and the 35 population adults using a Qiagen DNeasy Blood and Tissue Kit (Qiagen, Valencia CA).

A random subsample of five gravid females and three pups from each litter (to standardize for litter size), and 19 additional individuals of both sexes (males $\mathrm{n}=9$, females $n=10$ ) were selected for analysis of telomere length. The nine males ranged from $360-630 \mathrm{~mm}$ TL, including subadult and adult size classes. Females ranged from 490$910 \mathrm{~mm}$ TL including subadult and adult size classes. Gravid females " $\mathrm{G}$ " ranged from $695-805 \mathrm{~mm}$ TL. The "pups" category is comprised of individuals collected in utero at different developmental stages. The mean TL for each of the five litters are $30 \mathrm{~mm}, 65$ $\mathrm{mm}, 102 \mathrm{~mm}, 158 \mathrm{~mm}$, and $202 \mathrm{~mm}$. Individuals of differing sizes were selected to test 
whether telomere lengths are consistent in individuals of similar sizes and if there was is a significant association between telomere length and the size (i.e., TL as a proxy for age) of the sharks.

DNA purity checks and quantification were carried out via a Qubit Broad Range DNA Kit (Qubit, Thermo Fisher, Waltham MA). All concentrations were standardized to $0.5 \mathrm{ng} / \mu \mathrm{L}$ and were stored at $-20{ }^{\circ} \mathrm{C}$ until analysis. Primers standard for deuterostomes were used to measure telomere length via qPCR (F 5'CGGTTtGTTTGGGTTTGGGTTTGGGTTTGGGTTTGGGTT3'， R 5'GCGTTGCCTTACCCTTACCCTTACCCTTACCCTTACCCT3', (Farzaneh-Far et al. 2008). Assays were run on a StepOnePlus Real-time PCR System (ABI). Each 20uL reaction consisted of 10uL Power SYBR Green PCR Master Mix (Thermo Fisher, Waltham MA), $2 \mu \mathrm{L}$ forward primer $(1 \mu \mathrm{M}), 4 \mu \mathrm{L}$ reverse primer $(1 \mu \mathrm{M}), 3 \mu \mathrm{L}$ purified water and $1 \mathrm{uL}$ template DNA $(0.5 \mathrm{ng} / \mu \mathrm{L})$. Negative controls substituted $1 \mu \mathrm{L}$ of template DNA for an additional 1uL of purified water. All samples were run in triplicate and resulting Cycle Threshold $(\mathrm{Ct})$ values were averaged. The qPCR program was 10 min 95 ${ }^{\circ} \mathrm{C}, 40$ cycles of $15 \mathrm{~s} 95^{\circ} \mathrm{C}, 1 \mathrm{~min} 56 \mathrm{C}$. qPCR efficiency was verified via a standard curve of DNA concentration.

$\mathrm{Ct}$ values have an inverse relationship with telomere length and are calculated based on the number of cycles it takes for a large enough amount of material to be replicated. Therefore, the longer the telomere, the fewer number of cycles it will take to reach the threshold resulting in a lower $\mathrm{Ct}$ value, and the shorter the telomere, the more cycles it will take to reach the threshold resulting in a larger value (Farzaneh-Far et al., 2008). 
Using $\mathrm{Ct}$ values as a proxy for telomere length, they were plotted against TL in a linear regression to test for initial relationships between the two factors. One female outlier was calculated using Grubb's test $(\mathrm{p}=<0.01)$ and was removed from subsequent analyses. Pup's Ct values were also plotted independently in a linear regression against their TL, with individual litters having a unique shape identifier. One litter with a larger spread in values among the three pups, was compared to multiple paternity data from chapter 1 results. To see if there were any sex or life stage effects (females, gravid females, males, or pup) an ANOVA was run to compare these factors to Ct values.

\section{Results}

The linear regression including the female outlier showed a positive significant relationship between $\mathrm{Ct}$ value and $\operatorname{TL}\left(\mathrm{F}_{1,37}=7.91, \mathrm{r}^{2}=0.17, \mathrm{p}=0.0078\right)$, indicating that telomeres are shorter in larger and potentially older individuals. The linear regression was re-run without the female outlier and showed the strength of the predictive relationship improved $\left(\mathrm{F}_{1,36}=13.58, \mathrm{r}^{2}=0.27, \mathrm{p}=0.0007, \mathrm{Ct}=22.520992+0.0021034 *\right.$ Length $)$ (Figure 7), such that $27 \%$ of the variation in telomere length is explained by body size. 


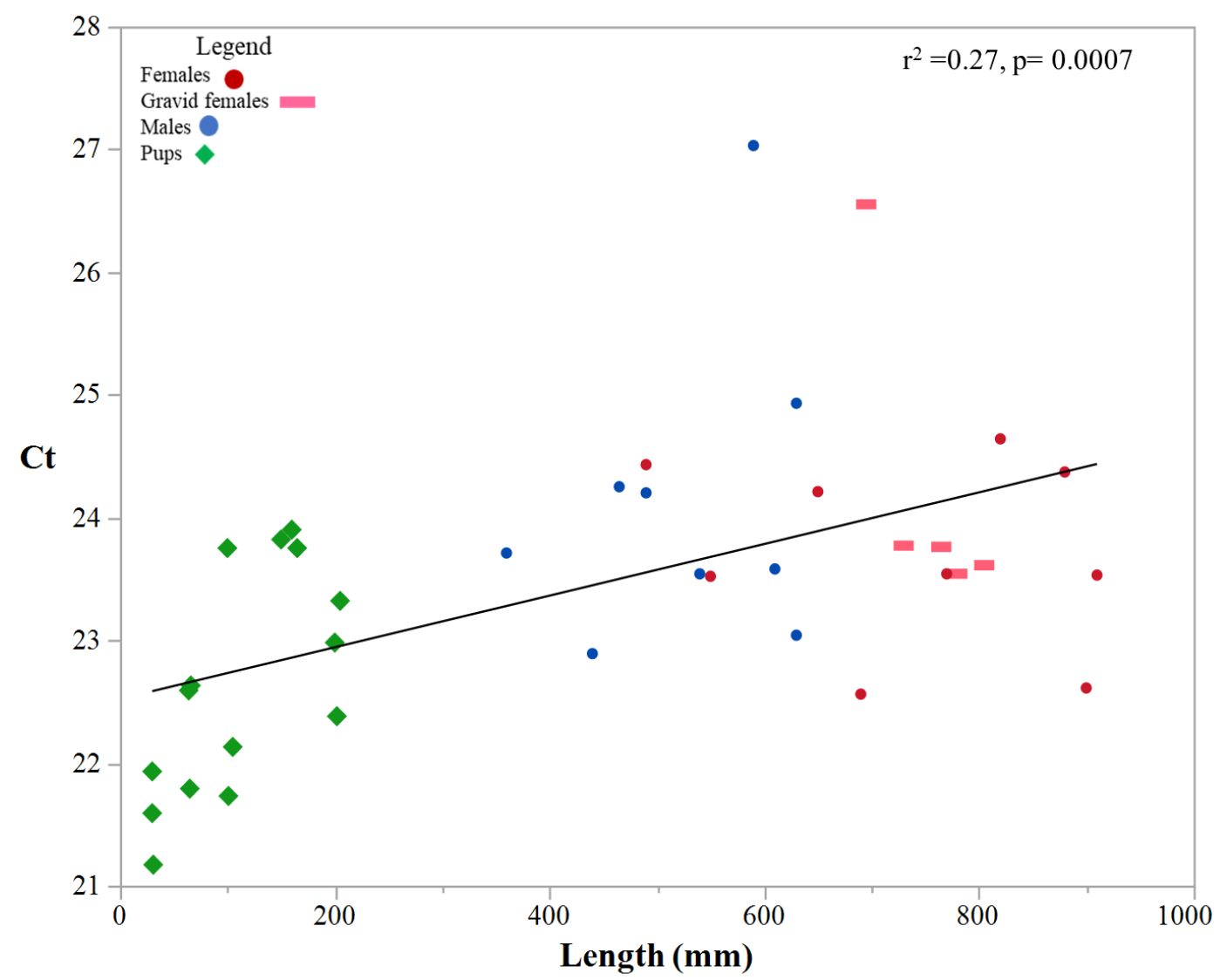

Figure 7. Relationship between $\mathrm{Ct}$ and total length showing a significant relationship between the two factors.

When the pups were plotted in a linear regression of TL to Ct value there was a significant association $(\mathrm{F} 1,13=9.8609, \mathrm{r} 2=0.43, \mathrm{p}=0.0078)$ where $\mathrm{Ct}$ value increased with increasing pup body size (Figure 8). The three pups from one of the litters has a larger spread of $\mathrm{Ct}$ values compared to the other litters. This litter happened to be the only litter analyzed that had pups that did not share a father and were cross-referenced from paternity data (Nehmens, Feldheim \& Ebert, in prep). The paternity data showed that the two pups that clustered together shared a sire, while the other pup from the same litter had a different sire. 
$\mathrm{Ct}$ values differed significantly between the sexes and life stages $\left(\mathrm{ANOVA}, \mathrm{F}_{3,34}=\right.$ 5.73, $\mathrm{p}=0.0028$ ) (Figure 9). A Tukey's HSD post-hoc test showed that females, gravid females, and males had significantly greater $\mathrm{Ct}$ values (i.e. shorter telomeres) than the pups $(\mathrm{p}=0.0172, \mathrm{p}=0.0044$, and $\mathrm{p}=0.0014$, respectively $)$.

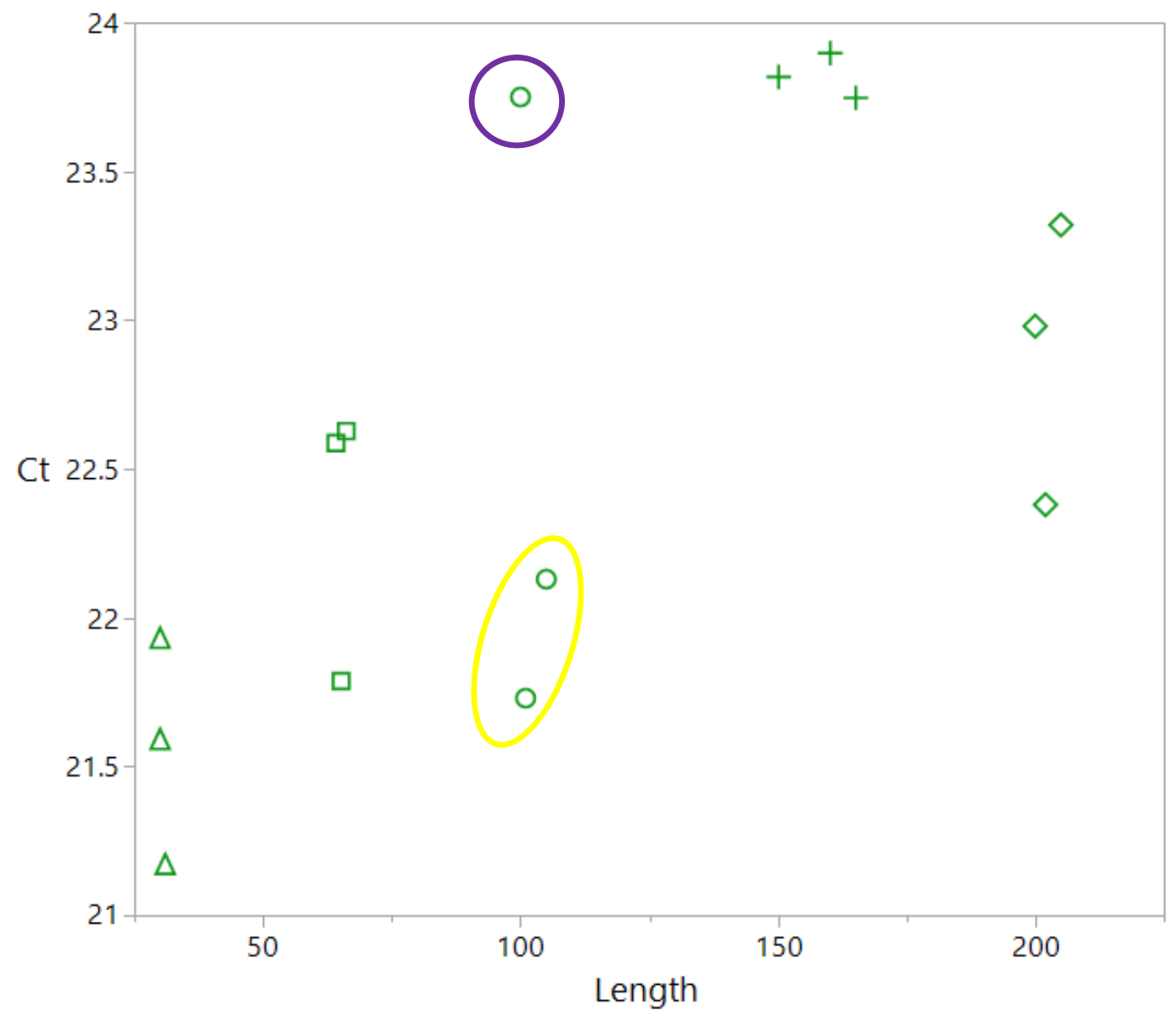

Figure 8. Pups from the litter depicted in circles have a larger spread in $\mathrm{Ct}$ values than other litters. The two pups circled in yellow share a sire, while the single individual circled in purple has a different sire. 


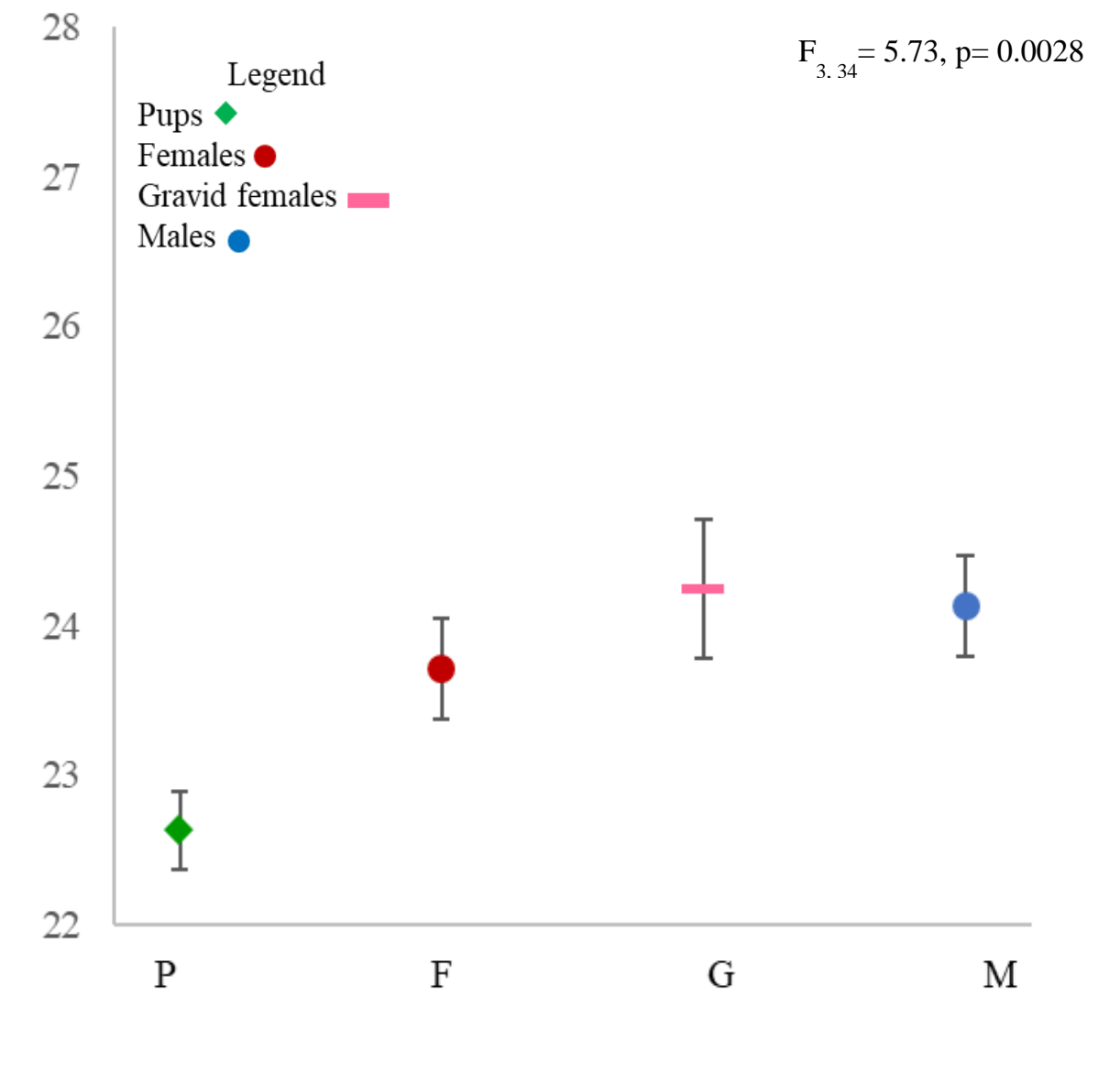

Figure 9. Comparison of sex, gravid females, males and pups showing that the pups have a significantly lower $\mathrm{Ct}$ value than the other groups.

\section{Discussion}

$\mathrm{Ct}$ values were used for analysis rather than quantifying the length of the telomeres from each individual (Varney, Pomory \& Janosik, 2017). Lower Ct values correspond to longer telomeres as previously established in Faranzah-Far et al. (2008). Given the qualitative and exploratory nature of this study, these were the established methods that would be most suited for this investigation.

The significant relationship comparing TL to $\mathrm{Ct}$ value $(\mathrm{p}=0.0078)$, provides evidence for the shortening of telomeres over the course of an individual's lifetime. Shortening of 
telomeres is a phenomenon seen in organisms across many taxa including birds and mammals (Haussmann et al., 2003), primates (Herbig, Ferreira, Condel, Carey \& Sedivy, 2006), and fish (Kishi et al., 2003).

The significant difference between females, gravid females, and males compared to pups supports telomerase activity during gamete formation. In many organisms, offspring (e.g. Mantell \& Greider, 1994; Wright, Piatyszek, Rainey, Byrd \& Shay, 1996; Betts \& King, 1999; Xu \& Yang, 2000) or regenerated body parts (Varney et al., 2017) activate telomerase to lengthen telomeres, making each generation or regeneration genetically younger than the previous (Schaetzlein et al. 2004). The significant relationship between pup length and $\mathrm{Ct}$ value provides support that telomerase activity may be mediated throughout development. As pups reach time at parturition, telomerase may no longer be active, and may continue to remain inactive leading to the shortening of telomeres throughout the lifespan of an individual.

The ageing process, while often thought of as a visible progression, is controlled by cellular activity. As cells continuously divide, telomere length slowly shortens until the cell senesces and undergoes apoptosis, or cell death (Blackburn, 1991). If an organism is able to maintain or even lengthen its telomeres, then cell death does not occur, and the organism would perceivably not age. Izzo et al. (2010) found there was no trend between telomere length and individuals of different size classes, showing no positive or negative correlation, for Heterodontus portusjacksoni, the Port Jackson's Shark, that inhabits shallow waters. In this study, the deep-sea shark, E. granulosus, showed statistically significant differences between size classes and telomere length, with a positive 
correlation between TL and Ct value, and $27 \%$ of the variability in telomere length explained by body size. This contrast between the two species from vastly different habitats is intriguing and warrants investigation into telomere dynamics across elasmobranch taxa and habitats beyond the ageing process (Bize, Criscuolo, Metcalfe, Nasir, \& Monaghan, 2009). Attention should be given to environmental conditions (Angelier, Vleck, Holberton \& Marra, 2013) and stressors, such as contaminants (Mizutani, Tomita, Niizuma \& Yoda, 2013), that are known to effect telomere length. Exploring how environment affects elasmobranch telomere length may provide a better understand the resiliency of this group of fishes.

The potential signal of multiple paternity within the pups examined, may prove to be another way to preliminarily test for multiple paternity. Relative paternal and maternal contributions to offspring telomere length is not yet well established, with predominantly avian studies producing contradictory results (Heidinger et al., 2016; Johnsen, Pauliny, Lifjeld \& Blomqvist, 2017). Further investigation of additional litters and corroboration with traditional methods using microsatellite markers (Nehmens et al., in prep) is needed, but the implications of a potential fitness-related effect of multiple paternity merits attention. Additionally, this signal, if accurate, may indicate discrepancies in telomere length at time of parturition that warrant further investigation. Assessing this and the rate of telomere shortening are important pieces of information in understanding telomere dynamics in this species. 


\section{Summary}

This study concluded that telomeres appear to shorten in relation to size (age). Although the sample size was small, these findings lay the groundwork for future studies of telomeres in relation to elasmobranch life history. Benefits from genetic studies like this one include non-destructive sampling that allows for continuous sampling throughout an organism's lifetime and a deeper understanding of how telomeres may change over time, within and among individuals. A shift from chronological age to a more biologically relevant perspective may be necessary to deepen our understanding of the paradigm of "ageing," (Blackburn 2000; Bize et al. 2009). Even if telomere shortening does not correlate directly with chronological age, it may provide other valuable information (Bateson 2015) related to reproductive fitness, embryonic development, contaminant effects, and more.

\section{Conclusion}

The conclusions from these studies show that the scientific paradigms we have come to align our rhetoric with do not always hold true and must be tested for accuracy. Even if most species maintain consistent patterns, it is a disservice to those that fall outside of those patterns which may have huge implications for a species' survival if they are treated inappropriately with respect to conservation. Additionally, it is important to consider creative or alternative approaches to traditional methods for investigating paradigms of species that are less accessible or where commonly used methods do not work, such as with Etmopterus granulosus. Using new approaches, as was done with these studies, has provided new insight to an understudied deep-sea species. 


\section{Literature Cited}

Angelier, F., Vleck, C.M., Holberton, R.L., \& Marra, P.P. (2013). Telomere length, nonbreeding habitat and return rate in male American redstarts. Functional Ecoogyl, 27, 342 - 350.

Baremore, I.E. \& Passerotti, M.S. (2013). Reproduction of the Blacktip Shark in the Gulf of Mexico. Marine and Coastal Fisheries: Dynamics, Management, and Ecosystem Science, 5, 127-138.

Bateman, A. J. (1948). Intra-sexual selection in Drosophila. Heredity, 2, 349-368.

Bateson, M. (2015). Cumulative stress in research animals: Telomere attrition as a biomarker in a welfare context? Bioessays. 38, 201-212.

Betts, D. H. \& King, W. A. (1999) Telomerase activity and telomere detection during early bovine development. Developmental Genetics, 25, 397-403.

Birkhead. T.R. \& Pizzari, T. (2002). Postcopulatory sexual selection. Nature reviews. Genetics, 3, 262-73.

Bize, P., Criscuolo, F., Metcalfe, N.B., Nasir, L., \& Monaghan, P. (2009). Proceedings of the Royal Society B, 276(1662), 1679-1683

Blackburn, E. H. (1991). Structure and function of telomeres. Nature, 350, 569-573.

Blackburn, E. H. (2000). Telomere states and cell fates. Nature, 408, 53-56.

Cailliet, G.M. (2015). Perspectives on elasmobranch life-history studies: a focus on age validation and relevance to fishery management. Journal of Fish Biology, 87, 1271-1292.

Cailliet, G. M., Martin L.K., Harvey, J.T., Kusher, D., \& Welden, B.A. (1983b). Preliminary studies on the age and growth of the blue, Prionace glauca, common thresher, Alopias vulpinus, and shortfin mako, Isurus oxyrinchus, sharks from California waters. U.S. Dep. Commer., NOAA Technical Report NMFSI, 8, 179188.

Cailliet, G. M., Radtke, R.L., \& Welden, B.A. (1986). Elasmobranch age determination and verification: a review. Indo-Pacific fish biology: proceedings of the second international conference on Indo-Pacific fishes. Tokyo, Japan: Ichthyological Society of Japan Tokyo (pp. 345-359). 
Cailliet, G. M. (1990). Elasmobranch age determination and verification: an updated review. In Elasmobranchs as living resources: advances in the biology, ecology, systematics, and the status of the fisheries. U.S. Department of Commerce, NOAA Technical Report NMFS, 90, 157-165.

Cailliet, G. M., Andrews, A. H., Burton, E. J., \& Watters, D. L. (2001). Age determination and validation studies of marine fishes: do deep-dwellers live longer? Experimental Gerontology, 36, 739-764.

Cailliet, G. M. \& Goldman, K. J. (2004). Age determination and validation in chondrichthyan fishes (. In Biology of Sharks and their Relatives (pp. 399-447). Boca Raton, FL: CRC Press.

Camhi, M., Fowler, S.L., Musick, J.A., Bräutigam, A. \& Fordham, S.V. (1998). Sharks and their Relatives - Ecology and Conservation. IUCN/SSC Shark Specialist Group. IUCN, Gland, Switzerland and Cambridge, UK.

Carlisle, A., King, A., Cailliet, G.M., Brennan, J.S. (2007). Long-term trends in catch composition from elasmobranch derbies in Elkhorn Slough, California. Marine Fisheries Review, 69, 25-45.

Chapman, D.D., Prodohl, P.A., Gelsleichter, J., Manire, C.A. \& Shivji, M.S. (2004). Predominance of genetic monogamy by females in a hammerhead shark, Sphyrna tiburo: implications for shark conservation. Molecular Ecology, 13, 1965-1974.

Clark, M.R., Anderson, O.F., Francis, R.I.C.C. \& Tracey, D.M. 2000. The effects of commercial exploitation on orange roughy (Haplostethus atlanticus) from the continental slope of the Chatham Rise, New Zealand, from 1979 to 1997. Fisheries research, 45, 217-238.

Clark, M. R., Watling, L., Rowden, A. A., Guinotte, J. M., \& Smith, C. R. (2011). A global seamount classification to aid the scientific design of marine protected area networks. Ocean \& Coastal Management, 54(1), 19-36.

Clerkin, P.J. (2017). Life history aspects and taxonomy of deep-sea chondrichthyans in the Southwestern Indian Ocean. San Jose State University, San Jose, USA.

Coelho, R., Fernandez-Carvalho, J., Lino, P.G., \& Santos, M.N. (2012). An overview of the hooking mortality of elasmobranchs caught in a swordfish pelagic longline fishery in the Atlantic Ocean. Aquatic Living Resources, 25, 311-319.

Compagno, L.J.V., Ebert, D.A., \& Smale, M.J. (1989). The sharks and rays of Southern Africa. Cape Town, South Africa: Struik Publishers. 
Compagno, J.V. \& Musick, J.A. (2005). Species Status Reports: Deepwater species. In: Fowler, S. L., Cavanagh, R. D., Camhi, M., Burgess, G. H., Cailliet, G. M., Fordham, S. V, Simpfendorfer, C.A. \& Musick, J. A. (comp. and ed.). Sharks, Rays and Chimaeras: The Status of the Chondrichthyan Fishes. Status Survey. IUCN/SSC Shark Specialist Group. IUCN, Gland, Switzerland and Cambridge, UK.

Cornell, S.J. \& Tregenza, T. (2007). A new theory for the evolution of polyandry as a means of inbreeding avoidance. Proceedings of the Royal Society Biological Sciences, 274 (1627), 2873-2879.

Daley, R.K., Steven, J.D., Last, P.R., \& Yearsley, G.K. 2002. Field guide to Australian sharks \& rays (1-84). Hobart, Australia: CSIRO Publishing.

DiBattista, J. D., Feldheim, K. A., Gruber, S. H. \& Hendry, A. P. (2008b). Are indirect genetic benefits associated with polyandry? Testing predictions in a natural population of lemon sharks. Molecular Ecology, 17, 783-795.

Dietrich, S \& Wulf-Heinrich, H. (1995). Hiev up: die So war die Hochseefischerei der DDR, Hamburg, 11. Dietrich, S and Wulf-Heinrich, H. (1995). Hive up: that was the deep-sea fishing of the GDR. Hamburg, Germany.

Dixon, A., Ross, D., O’Malley, S.L.C., \& Burke, T. (1994) Paternal investment inversely related to degree of extra-pair paternity in the reed bunting. Nature, 371, 698-700.

Ebert, D.A. (2015). Deep-Sea cartilaginous fishes of the Southeastern Atlantic Ocean. FAO Species Catalogue for Fishery Purposes No. 9.

Ebert, D.A., Fowler, S. \& Compagno, L. (2013). Sharks of the world. Plymouth, Massachusetts: Wild Nature Press.

Emlen, S.T., \& Oring, L.W. (1977). Ecology, sexual selection, and the evolution of mating systems. American Association for the Advancement of Science, 197 (4300), 215-223.

F. A. O. (2009). Report of the Workshop on deep-sea species identification. Rome, Itlay: FAO Fisheries and Aquaculture Report No. 947.

Farzaneh-Far, R., Cawthon, R.M., Na, B., Browner, W.S., Schiller, N.B., \& Whooley, M.A. (2008). Prognostic value of leukocyte telomere length in patients with stable coronary artery disease data from the heart and soul study. Arteriosclerosis, Thrombosis, and Vascular Biology, 28, 1379-1384. 
Feldheim, K.A., Gruber, S.H. \& Ashley, M.V. (2004). Reconstruction of parental microsatellite genotypes reveals female polyandry and philopatry in the Lemon Shark, Negaprion brevirostris. Evolution, 58 (10), 2332-2342.

Feldheim, K.A., Gruber, S.H., DiBattista, J.D., Babcock, E.A., Kessel, S.T., Hendry, A.P., Pikitch, E.K., Ashley, M.V., \& Chapman, D.D. (2014). Two decades of genetic profiling yields first evidence of natal philopatry and long-term fidelity to parturition sites in sharks. Molecular Ecology, 23, 110-117.

Finucci, B., Dunn, M.R. \& Jones, E.G. (2018). Aggregations and associations in deep-sea chondrichthyans. ICES Journal of Marine Science. doi:10.1093/icesjms/fsy034.

Finucci, B. \& Lamilla, J. (2018). Etmopterus granulosus. The IUCN Red List of Threatened Species 2018: e.T116856245A3120311. http://dx.doi.org/10.2305/IUCN.UK.2018-2.RLTS.T116856245A3120311.en. Downloaded on 02 February 2019.

Frasier, T.R. (2008). STORM: software for testing hypotheses of relatedness and mating patterns. Molecular Ecology Resources, 8, 1263-1266.

Garza, J.C. \& Williamson, E.G. (2001). Detection of reduction in population size using data from microsatellite loci. Molecular Ecology, 10, 305-318.

Harry, A. V. (2018). Evidence for systemic age underestimation in shark and ray ageing studies. Fish and Fisheries, 19(2), 185-200.

Haskell, W.L., (1949). An investigation of the possibility of determining the age of sharks through annuli as shown in cross sections of vertebrae. Annual Report Marine Laboratory Texas Game Fish Oyster Commission, 212-217.

Haussmann, M.F., Winkler, D.W., \& O'Reilly, K.M. (2003b) Telomeres shorten more slowly in long-lived birds and mammals than in shortlived ones. Proceedings of the Royal Society of London B Series, 270, 1387-1392.

Haussmann, M.F., \& Heidinger, B.J. (2015). Telomere dynamics may link stress exposure and ageing across generations. Biology Letters, 11, 20150396. doi.org/10.1098/rsbl.2015.0396

Heidbrink, I. (2011). A Second Industrial Revolution in the Distant-Water Fisheries? Factory-Freezer Trawlers in the 1950s and 1960s. International Journal of Maritime History, 23(1), 179-192. 
Heidingerm, B.J., Herborn, K.A., Granroth-Wilding, H.M.V., Boner, W., Burthe, S., Newell, M., Wanless, S., Daunt, F. \& Monaghan, P. (2016). Parental age influences offspring telomere loss. Functional Ecology, 30, 1531-1538.

Herbig, U., Ferreira, M., Condel, L., Carey, D. \& Sedivy, J. M. 2006 Cellular senescence in aging primates. Science, 311, 1257.

Hixon, M.A., Johnson, D.W. \& Sogard, S.M. (2013). BOFFFFs: on the importance of conserving old-growth age structure in fishery populations. ICES Journal of Marine Science. doi:10.1093/icesjms/fst200.

Holden,M. J. \& Vince, M. R. (1973). Age validation studies on the centra of Raja clavata using tetracycline. Journal du Conseil international pour l'Exploration de la Mer, $35,13-17$.

Holman, L. \& Kokko, H. (2013). The consequences of polyandry for population viability, extinction risk and conservation. Philosophical Transactions of the Royal Society B, 368 (1613), 1-12.

Irvine, S.B., Stevens, J.D., \& Laurenson, L.J.B. (2006). Comparing external and internal dorsal-spine bands to interpret the age and growth of the giant lantern shark, Etmopterus baxteri (Squaliformes: Etmopteridae). Environmental Biology of Fishes, 77(3-4), 253-264.

Ishiyama, R. (1951 $a$ ). Studies on the rays and skates belonging to the family Rajidae, found in Japan and adjacent regions. 2. On the age-determination of Japanese black-skate Raja fusca Garman (preliminary report). Bulletin of the Japanese Society of Scientific Fisheries, 16, 112-118.

Ishiyama, R. (1951 b). Studies on the rays and skates belonging to the family Rajidae, found in Japan and adjacent regions. (3). Age determination of Raja hollandi Jordan and Richardson, chiefly inhabiting in thewaters of the EastChina Sea. Bulletin of the Japanese Society of Scientific Fisheries, 16, 119-124.

Izzo, C., Bertozzi, T., Donnellan, S., \& Gillanders, B.M. (2010). Telomere Length Varies Independently of Age in the Port Jackson Shark, Heterdontus portusjacksoni: With a commentary on telomere length measurement methods. Chapter 2. PhD Thesis School of Earth and Environmental Sciences at the University of Adelaide, South Australia.

Jirik, K.E. \& Lowe, C.G. (2012). An elasmobranch maternity ward: female round stingrays Urobatis halleri use warm, restored estuarine habitat during gestation. Journal of Fish Biology, 80, 1227-1245. 
Johnsen, A., Pauliny, A., Lifjeld, J.T., \& Blomqvist, D. (2017) Is telomere length associated with mate choice in a songbird with a high rate of extra-pair paternity? PLoS ONE, 12(8), e0182446.

Jones, A.G. (2001) gerud1.0: a computer program for the reconstruction of parental genotypes from progeny arrays using multilocus DNA data. Molecular Ecology Notes, 1, 215-218

Jones, O.R. \& Wang, J. (2010). COLONY: a program for parentage and sibship inference from multilocus genotype data. Molecular Ecology Resources, 10, 551-555.

Kaganovskaya, S.M. (1933). Method of Age Determination and composition of catchers of Spiny Dogfish (Squalus acanthias). Vestnik Dal'nevostochnogo Filiala Akademii Nauk SSSR, 1(3), 139-141.

Kalish, J.M. (1993). Pre and post bomb radiocarbon in fish otoliths. Earth and Planetary Scientific Letters, 114, 549-554.

King, J.R. \& Withler R.E. (2005). Male nest site fidelity and female serial polyandry in lingcod (Ophiodon elongatus, Hexagrammidae). Molecular Ecology, 14, 653660.

Kishi, S., Uchiyama, J., Baughman, A.M., Goto, T., Lin, M.C., \& Tsai, S.B. (2003). The zebrafish as a vertebrate model of functional aging and very gradual senescence. Experimental Gerontology, 38, 777-786.

Kyne, P.M. \& Simpfendorfer, C.A. (2010).Deepwater Chondrichthyans. In: Carrier, J.C., Musick, J.A. \& Heithaus, M.R. (Eds.). Sharks and Their Relatives II. Biodiversity, Adaptive Physiology, and Conservation (pp.37-113). BocaRaton, Florida: CRCPress.

Lack, D. (1968). Ecological Adaptations for Breeding in Birds. London, England: Methuen Ltd.

Maddox, D.J. \& Feldheim, K.A. (2014). A cost-effective size standard for fragment analysis that maximizes throughput on five dye set platforms. Conservation Genetics Resources, 6, 5-7.

Maduna, S.N., Van Wyk, J.H., Da Silva, C., Gennari, E. \& Bester-Van Der Merwe, A.E. (2018). Evidence for sperm storage in common smoothhound shark Mustelus mustelus and paternity assessment in a single litter from South Africa. Journal of Fish Biology, 92, 1183-1191. 
Mantell, L. L. \& Greider, C. W. (1994). Telomerase activity in germline and embryonic cells of Xenopus. The EMBO Journal, 13, 3211-3217.

Mizutani, Y., Tomita, N., Niizuma, Y., \& Yoda, K., (2013). Environmental perturbations influence telomere dynamics in long-lived birds in their natural habitat. Biology Letters, 9, 20130511.

Natanson, L.J. (1984). Aspects of the age, growth, and reproduction of the Pacific Angel Shark, Squatina Californica, off Santa Barbara, California. Master's Thesis. Department of Biology, San Jose State University.

Natanson, L. J., \& Cailliet, G. M. (1986). Reproduction and development of the Pacific Angel Shark, Squatina californica, off Santa Barbara, California. Copeia, 4, 98794.

Natanson, L. J., \& Cailliet, G. M. (1990). Vertebral growth zone deposition in Pacific Angel Sharks. Copeia, 4, 1 133-45.

Natanson, L. J.,Wintner, S. P., Johansson, F., Piercy, A., Campbell, P.,De Maddalena,A., Gulak, S. J. B., Human, B., Fulgosi, F. C., Ebert, D. A., Hemida, F., Mollen, F. H., Vanni, S., Burgess, G. H., Compagno, L. J. V. \& Wedderburn-Maxwell, A. (2008). Ontogenetic vertebral growth patterns in the basking shark Cetorhinus maximus. Marine Ecology Progress Series, 36, 267-278.

Natanson, L.J., Skomale, G.B., Hoffmann, S.L., Porter, M.E., Goldman, K.J., \& Serra, D. (2018). Age and growth of sharks: do vertebral band pairsrecord age? Marine and Freshwater Research, 69(9), 1440-1452.

Nehmens, M.C., Feldheim, K.A., \& Ebert, D.A. (2018). Understanding what we cannot see: a genetic approach to the mating system of the Southern Lanternshark, Etmopterus granulosus. In prep.

Nespolo, R.F. \& Bacigalupe, L.D. (2009). Viability selection on early body mass and the effect of female body size on fecundity: a study on the leaf-eared mouse Phyllotis darwini. Ecological Research, 24, 997-1002.

Nielsen, J., Hedeholm, R.B., Heinemeier, J., Bushnell, P.G., Christiansen, J.S., Olsen, J., Ramsey, C.B., Brill, R.W., Simon, M., Steffensen, K.F., \& Steffensen, J.F. (2016). Eye lens radiocarbon reveals centuries of longevity in the Greenland Shark (Somniosus microcephalus). Science, 353(6300), 702-704.

Officer, R. A., Gason, A. S., Walker, T. I., \& Clement, J. G. (1996). Sources of variation in counts of growth increments in vertebrae from gummy shark, Mustelus antarcticus, and school shark, Galeorhinus galeus: implications for age 
determination. Canadian Journal of Fisheries and Aquatic Sciences, 53, 17651777 .

Pardo, S.A., Cooper, A.B. \& Dulvy, N.K. (2013) Avoiding fishy growth curves. Methods in Ecology and Evolution, 4, 353-360.

Page, R.E. (1980). The evolution of multiple mating behavior by honey bee queens (Apis mellifera L.). Genetics, 96, 265-273.

Pankhurst, N.W., McMillan, J. \& Tracey, D.M. (1987). Seasonal reproductive cycles in three commercially exploited fishes from the slope waters off New Zealand. Journal of Fish Biology, 30, 193-211.

Pearse, D.E., Janzen, F.J., \& Avise, J.C. (2001). Genetic markers substantiate long-term storage and utilization of sperm by female painted turtles. Journal of Heredity, 86, $378-384$.

Pitcher T.J., Morato T.,Hart P.J.B., Clark M.R., Haggan N., \& Santos R.S. (2007). Seamounts: Ecology, Fisheries, and Conservation. Vol. 12. Black-well, Oxford, UK.

Porter, M.E., Beltrán, J.L., Koob, T.J., \& Summers, A.P. (2006). Material properties and biochemical composition of mineralized vertebral cartilage in seven elasmobranch species (Chondrichthyes). The Journal of Experimental Biology, 209, 2920-2928.

Pratt, H.L., Jr. (1993). The storage of spermatozoa in the oviducal glands of Western North Atlantic sharks. Environmental Biology of Fishes, 38, 139-149.

Priede, I. G., Froese, R., Bailey, D. M., Bergstad, O. A., Collins, M. a, Dyb, J. E., ... King, N. (2006). The absence of sharks from abyssal regions of the world's oceans. Proceedings Royal Society Biological Sciences, 273(1592), 1435-41.

Raymond, M. \& Rousset, F. (1995). Genepop (version 1.2): population genetics software for exact tests and ecumenicism. Heredity, 86, 248-249.

Ridewood, W. G. (1921). On the calcification of the vertebral centra in sharks and rays. Philosophical Transactions of the Royal Society B, 210, 311-407.

Rocco, L., Morescalchi, M.A., Costagliola, D., \& Stingo, V. (2002). Karyotype and genome characterization in four cartilaginous fishes. Genetics, 295, 289-298.

Rousset, F. (2008). Genepop'007: a complete reimplementation of the Genepop software for Windows and Linux. Molecular Ecology Resources, 8, 103-106. 
Schaetzlein, S., Lucas-Hahn, A., Lemme, E. Kues, W.A., Dorsch, M., Manns, M.P., Niemann, H. \& Rudolph, K.L. (2004). Telomere length is reset during early mammalian embryogenesis. Proceedings of the National Academy of Science USA, 101, 8034-8038.

Schuelke, M. (2000). An economic method for the fluorescent labeling of PCR fragments: A poor man's approach to genotyping for research and highthroughput diagnostics. Nature Biotechnology, 18, 233-234.

Simpfendorfer, C. A., \& Kyne, P. M. (2009). Limited potential to recover from overfishing raises concerns for deep-sea sharks, rays and chimaeras.

Environmental Conservation, 36 (2), 97-103.

SIODFA: Fishing in the SIO. c2010. Southwestern Indian Ocean. Southern Indian Ocean Deepsea Fishers Association. [accessed 2018 October 22]. http://www.siodfa.org/.

Smart, J.J., Chin, A., Tobin, A.J. \& Simpfendorfer, C.A. (2016). Multimodel approaches in shark and ray growth studies: strengths, weaknesses and the future. Fish and Fisheries, 17, 955-971.

Stevens, J. D., Bonfil, R., Dulvy, N. K., \& Walker, P. A. (2000). The effects of fishing on sharks, rays, and chimaeras (chondrichthyans), and the implications for marine ecosystems. ICES Journal of Marine Science, 57(3), 476-494.

Stockley, P., Searle, J.B., Macdonald, D.W. \& Jones, C.S. (1993). Female Multiple Mating Behaviour in the Common Shrew as a Strategy to Reduce Inbreeding. Proceedings of the Royal Society Biological Sciences, 254 (1341), 173-179.

Straube, N., Kriwet, J. \& Schliewen, U.K. (2011). Cryptic diversity and species assignment of large lantern sharks of the Etmopterus spinax clade from the Southern Hemisphere (Squaliformes, Etmopteridae). Zoologica Scripta, 40(1), $61-75$.

Straube, N., Leslie, R.W., Clerkin, P.J., Ebert, D.A., Rochel, E., Corrigan, S., Li, C. \& Naylor, G.J. (2015). On the occurrence of the Southern Lanternshark, Etmopterus granulosus, off South Africa, with comments on the validity of E. compagnoi. Deep Sea Research Part II: Topical Studies in Oceanography, 115, 11-17.

Strohbusch, E. (1967) "Trawler," in Handbuch der werften, Bd. IX (pp17-63). Hamburg,Germany.

Strutt, I. (2001). Fleet Flops on seamounts: mountains of debt from Indian Ocean. Fish News International, 41(1), 1. 
Taylor, M.L., Price, T.A.R. \& Wedell, N. (2014). Polyandry in nature: a global analysis. Trends in Ecology and Evolution, 29 (7): 376-383.

Varney, R.M., Pomory, C.M., \& Janosik, A.M. (2017). Telomere elongation and telomerase expression in regenerating arms of the starfish Luidia clathrata (Asteroidea: Echinodermata). Marine Biology, 164(195), 1-6.

Wang, J. (2004). Sibship reconstruction from genetic data with typing errors. Genetics, 166, 1963-1979.

Wetherbee, B. M. (1996). Distribution and reproduction of the southern lantern shark from New Zealand. Journal of Fish Biology, 49, 1186-1196.

Wiebe, K.L. \& Martin, K. (1998). Age-specific patterns of reproduction in White-tailed and Willow Ptarmigan Lugopus leucurus and L. lugopus. IBIS International Journal of Avian Science, 140, 14-24.

Wilderbuer, T.K. \& Turnock, B.J. (2009). Sex-specific natural mortality of Arrowtooth Flounder in Alaska: implications of a skewed sex ratio on exploitation and management. North American Journal of Fisheries Management, 29, 306-322.

Wilson, A.B. \& Martin-Smith, K.M. (2007). Genetic monogamy despite social promiscuity in the pot-bellied seahorse (Hippocampus abdominalis). Molecular Ecology, 16, 2345-2352.

Wright, W. E., Piatyszek, M. A., Rainey, W. E., Byrd, W. \& Shay, J. W. (1996). Telomerase activity in human germline and embryonic tissues and cells. Developmental Genetics, 18, 173-179.

Xu, J. \& Yang, X. (2000) Telomerase activity in bovine embryos during early development Biology of Reproduction, 63, 1124-1128. 